\title{
Comparative Advantage, Demand for External Finance, and Financial Development*
}

\author{
Quy-Toan Do \\ The World Bank
}

\author{
Andrei A. Levchenko \\ International Monetary Fund
}

\begin{abstract}
The differences in the levels of financial development between advanced and developing countries are large and persistent. Theoretical and empirical literature has argued that these differences are the source of comparative advantage and could therefore shape trade patterns. This paper points out the reverse link: financial development is influenced by comparative advantage. We illustrate this idea using a model in which a country's financial development is an equilibrium outcome of the economy's productive structure: financial systems are more developed in countries with large financially intensive sectors. After trade opening demand for external finance, and therefore financial development, are higher in a country that specializes in financially intensive goods. By contrast, financial development is lower in countries that primarily export goods which don't rely on external finance. We demonstrate this effect empirically using data on financial development and export patterns in a panel of 96 countries over the period 1970-99. Using trade data, we construct a summary measure of a country's external finance need of exports, and relate it to the level of financial development. In order to overcome the simultaneity problem, we adopt a strategy in the spirit of Frankel and Romer (1999). We exploit sector-level bilateral trade data to construct, for each country and time period, a predicted value of external finance need of exports based on the estimated effect of geography variables on trade volumes across sectors. Our results indicate that financial development is an equilibrium outcome that depends strongly on a country's trade pattern.
\end{abstract}

JEL Classification Codes: F02, F14, O16, O19.

Keywords: trade patterns, demand for external finance, financial development, gravity model.

\section{World Bank Policy Research Working Paper 3889, April 2006}

The Policy Research Working Paper Series disseminates the findings of work in progress to encourage the exchange of ideas about development issues. An objective of the series is to get the findings out quickly, even if the presentations are less than fully polished. The papers carry the names of the authors and should be cited accordingly. The findings, interpretations, and conclusions expressed in this paper are entirely those of the authors. They do not necessarily represent the view of the World Bank, its Executive Directors, or the countries they represent. Policy Research Working Papers are available online at http://econ.worldbank.org.

We are grateful to Daron Acemoglu, Abhijit Banerjee, Thorsten Beck, Olivier Blanchard, Simon Johnson, Aart Kraay, Roberto Rigobon, Alan Winters and workshop participants at MIT and the World Bank for helpful comments. The views expressed in this paper are those of the authors and should not be attributed to the International Monetary Fund, the World Bank, their Executive Boards, or their respective managements. Correspondence: International Monetary Fund, 700 19th St. NW, Washington, DC 20431. Email: qdo@worldbank.org; alevchenko@imf.org. 


\section{Introduction}

A quick glance at levels of financial development across countries reveals large differences. Figure 1 plots for developing and advanced countries the ratios of private credit to GDP and trade openness to GDP starting in 1970. The average share of private credit to GDP is more or less three times higher in advanced countries than in developing ones throughout the period. On the other hand, trade volume as a share of GDP grew faster in developing countries, which have now surpassed the advanced ones. What explains persistent financial underdevelopment? Can we say something about the relationship between financial development and trade openness?

The literature has often emphasized the idea that financial development is an endowment. La Porta, Lopez-de-Silanes, Shleifer and Vishny (1998) provide empirical evidence that a country's legal origin is a strong and arguably exogenous determinant of a country's financial development. When it comes to institutions more broadly, Acemoglu, Johnson and Robinson (2001) document that the quality of institutions is largely determined by settler mortality rates during the colonial period. Applying these insights to international trade immediately suggests a pattern of comparative advantage: countries endowed with better financial systems will specialize in goods that rely on external finance in production. Indeed, this idea has been formalized theoretically by Kletzer and Bardhan (1987), Baldwin (1989), and Ju and Wei (2005), and has found empirical support in a number of studies (e.g. Beck, 2002, 2003, Becker and Greenberg, 2003, Svaleryd and Vlachos, 2005, and Manova, 2005).

The purpose of this paper is to show the reverse link: financial development itself depends on trade patterns. We argue that financial development is endogenous, and that it will be determined in part by demand for external finance in each country. Comparative advantage in trade will affect a country's production pattern, and in turn its demand for external finance. Countries specializing in financially dependent goods will have high demand for external finance and thus a high level of financial intermediation. On the other hand, the financial system will be less developed in countries that specialize in goods not requiring external finance. In this paper, we first illustrate this point using a very simple model in which goods differ in their reliance on external finance. Comparative advantage implies that after trade opening, the financially intensive sector expands in one country and disappears in the other. This change in production patterns in turn has implications for equilibrium financial development in the trading countries.

We then demonstrate this effect empirically. For a panel of 96 countries and 30 years, we use industry-level export data and information on each industry's reliance on external finance from Rajan and Zingales (1998) to build a measure of the external finance need of exports. This measure, constructed following the methodology of Almeida and Wolfenzon (2005), summarizes the demand 
for external finance that comes from a country's export pattern. We then use a comprehensive dataset on financial development first introduced by Beck, Demirguc-Kunt, and Levine (2000) to show that a country's financial development is strongly and robustly affected by the external finance need of its exports. The effect we find is economically significant. Our most conservative coefficient estimates imply that moving from the 25th to the 75 th percentile in the distribution of external finance need of exports is associated with an increase in financial development of about 0.33 standard deviations, or a 12 percentage point increase in private credit to GDP.

A key feature of this paper is the way it addresses the simultaneity problem arising in this exercise. We require an instrument for a country's export pattern. In order to construct it, we expand the geography-based methodology of Frankel and Romer (1999). These authors use the gravity model to predict bilateral trade volumes between each pair of countries based on a set of geographical variables, such as bilateral distance, common border, area, and population. Summing up across trading partners then yields, for each country, its "natural openness:" the overall trade to GDP as predicted by its geography. Because we need an instrument for trade patterns rather than total trade volumes, our point of departure is to estimate the Frankel and Romer gravity regressions in each industry. Following their methodology, we can then obtain the predicted trade volume as a share of GDP not just in each country, but also in each sector within each country. ${ }^{1}$ Doing so allows us to construct each country's predicted external finance need of exports, based on its predicted trade shares in each sector. We then use it as an instrument for the actual external finance need of exports. As a further extension of the Frankel and Romer approach, we perform this exercise for each five-year period between 1970 and 1999, giving a time dimension to our instrument.

The model we use to illustrate our point has two sectors, one of which relies on external finance. The size of the financial system, that is, the amount of borrowing and lending that occurs in the economy, is naturally a function of total output in the financially intensive sector. An additional feature of our theoretical setup is that the quality of the financial system is a function of its size. A larger financial sector leads to the greater ease with which entrepreneurs are able to fulfill the need for external finance. This is because when entrepreneurs start financially intensive projects and engage the country's financial system, they add liquidity. They become potential providers of external finance for fellow entrepreneurs, reducing the likelihood of financial distress. Each entrepreneur who invests in the financially intensive sector hence generates a positive spillover by increasing financial depth. ${ }^{2}$ Opening to trade will affect demand for external finance in both trading

\footnotetext{
${ }^{1}$ This strategy is adapted from di Giovanni, Levchenko, and Ranciere (2005).

${ }^{2}$ In modeling the market for external finance and the positive effect of financial system size on its quality, we abstract from the informational and enforcement frictions that are often invoked in this context. One can clearly adopt this approach as well, and think of the quality of the financial system in terms of how well it can overcome
} 
countries. In particular, the financial system deepens in a country that increases production of the financially dependent good. In the other country the financially dependent sector shrinks, leading to a deterioration in the size and quality of the country's financial system.

The assumptions underlying our model find support in empirical studies which relate the size of financial systems to their quality. Levine and Schmukler (2005) find evidence of a causal link between market size and financial depth: when looking at domestic market liquidity in emerging economies, they find that when some firms decide to raise finance abroad, the remaining domestic firms' trading liquidity is adversely affected. Note also that in most empirical studies of financial development, the positive association between size and quality is implicit. The quality of a financial system - financial development - is often proxied by measures of market size such as ratios of private credit to GDP or stock market capitalization to GDP.

This paper is not the first to explore the effect of trade on financial development. Rajan and Zingales (2003) argue that trade opening, especially when combined with openness to capital flows, weakens the incentives of incumbent firms to block financial development in order to reduce entry and competition. Furthermore, the relative political power of incumbents may decrease with trade as well. Thus, these authors argue that trade has a beneficial impact on financial development. Braun and Raddatz (2005) explore the political channel further. They demonstrate that in countries where trade liberalization reduced the power of groups most interested in blocking financial development, the financial system improved. If, on the other hand, trade opening strengthened those groups, external finance suffered. This paper can be thought of as complementary to Rajan and Zingales (2003) and Braun and Raddatz (2005). While these two studies are about how trade affects the supply of external finance, this paper is instead about the demand side.

It is also important to note that trade may affect financial development through a variety of other channels. Newbery and Stiglitz (1984) argue that trade, by affecting price elasticity, can potentially increase uncertainty and income volatility. Financial development could then be fostered by increased demand for insurance, though Broner and Ventura (2006) show that the outcome is sensitive to assumptions about the nature of asset market frictions. ${ }^{3}$ While a Newbery and Stiglitztype of argument invokes the role of financial markets for insuring risk in consumption, in this paper the financial system plays a role on the production side. Thus, in contrast to the consumption insurance view, our focus in on the differential impact of trade across countries as a function of the

these distortions and achieve the efficient level of lending. A positive link between the size of the financial markets and their ability to resolve such frictions has been modeled, for example, by Acemoglu and Zilibotti (1999).

${ }^{3}$ Rodrik (1998) shows that more open countries have larger governments to help them deal with increased uncertainty that is associated with openness. Svaleryd and Vlachos (2002) provide empirical evidence that countries with better developed financial systems are more likely to be open to trade, and argue this is because a better financial system allows a country to better cope with increased uncertainty. Tangentially, these authors also provide some evidence that the financial system improves after trade opening. 
pattern of comparative advantage.

The rest of the paper is organized as follows. Section 2 presents a stylized model of an economy in which the quality of a financial system and its size are jointly determined. We then open the economy to trade and look at the changes in the financial system size and quality as a function of comparative advantage. In Section 3, we discuss our empirical methodology and construct a measure of external finance need of exports, as well as an instrumental variable that will allow us to identify the causal impact of trade on financial development. The data used in this paper are described in Section 4. Our estimation results are presented in Section 5, and Section 6 concludes.

\section{The Model}

\subsection{The Environment}

Consider an economy with 1 factor, $L$ (labor) and 2 goods: a financially dependent good $F$ and a simple good $A$. The time horizon consists of the interval $t \in[0,1]$, and consumption takes place at $t=1$. Utility is Cobb-Douglas in the two goods:

$$
U\left(c_{F}, c_{A}\right)=c_{F}^{\alpha} c_{A}^{1-\alpha}
$$

Let good $A$ be the numeraire, and $p_{F}$ be the relative price of good $F$ in terms of $A$. Utility maximization implies the following relationship between consumption and the relative price:

$$
p_{F}=\frac{\alpha}{1-\alpha} \frac{c_{A}}{c_{F}}
$$

There is a potentially infinite number of entrepreneurs that can produce either $A$ or $F$. Entrepreneurs make the decision to enter either of the two intermediate goods sectors at $t=0$. Production in the two sectors then occurs continuously in the interval $t \in[0,1]$. Good $A$ is produced with a linear technology that requires one unit of $L$ to produce one unit of $A$. Profit maximization in that sector implies that the price of $A$ is equal to the wage $w: p_{A}=w=1$.

Good $F$ relies on external finance. Setting up a production unit of good $F$ requires one unit of $L$. A project in the $F$ sector consists of a continuous flow of returns $\left(R_{t}\right)_{t \in[0,1]}$. In each time interval $[t, t+d t]$, the project experiences a liquidity shock $\tilde{\lambda}_{t} d t$ of the following form:

$$
\tilde{\lambda}_{t}=\left\{\begin{array}{cl}
\lambda & w / \text { prob. } \frac{1}{2} \\
-\lambda & w / \text { prob. } \frac{1}{2}
\end{array}\right.
$$

where $\lambda$ is a positive constant. We assume that shocks are i.i.d. across time and firms, and cannot be saved. If in the interval $[t, t+d t]$, the liquidity shock is positive, or the liquidity need is fulfilled, then the project yields a flow of returns $R d t$; otherwise it returns 0 in that instant. ${ }^{4}$

\footnotetext{
${ }^{4}$ If there is an instant at some $t \in[0,1]$ in which the project returns 0 , it is not liquidated completely: the next instant it may produce again.
} 
Agents with a liquidity need can borrow to fulfill it. At each time interval $[t, t+d t]$, there exists a spot credit market in which entrepreneurs with excess liquidity lend to financially distressed agents at the prevailing interest rate $r_{t}$. Debt contracted in the time interval $[t, t+d t]$ is a claim on $t=1$ returns. As we assume spot credit markets, $r_{t}$ is determined by demand and supply of liquidity: if the aggregate liquidity shock is positive, then there is excess supply of finance and interest rates drop to zero. On the other hand, when there is a negative aggregate liquidity shock, lenders capture the entire benefit of refinancing the project so that $r_{t} \lambda d t=p_{F} R d t$. In the latter case, there are some projects with unfulfilled liquidity needs which yield zero return that instant.

How can we determine the total output in the $F$ sector? Let $\eta$ be the share of the labor force $L$ employed in the $F$ sector. Then the total number of firms in that sector is $\eta L$, and we index those firms by $i \in\{1, \ldots, \eta L\} .^{5}$ The cumulative output in this sector depends on how many projects are liquidated in each interval $[t, t+d t]$, and therefore on aggregate liquidity in each instant. Let $\gamma_{t}$ be the fraction of projects that are liquidated in the time interval $[t, t+d t]$. It is given by:

$$
\gamma_{t}= \begin{cases}\frac{1}{\lambda \eta L} \sum_{i=1}^{\eta L} \tilde{\lambda}_{t}^{i} & \text { if } \sum_{i=1}^{\eta L} \tilde{\lambda}_{t}^{i}<0 \\ 0 & \text { otherwise }\end{cases}
$$

The sum of all the shocks across firms in the $F$ sector, $\sum_{i=1}^{\eta L} \tilde{\lambda}_{t}^{i}$, gives the aggregate liquidity in this economy at time $t$. If it is positive, no projects are liquidated. If it is negative, the fraction of projects that are liquidated depends on the magnitude of the negative aggregate shock. Assuming projects are liquidated at random when aggregate liquidity is negative, the cumulative output realized by each firm in sector $F$ is given by $R[1-\gamma(\eta L)]$, where $\gamma(\eta L) \equiv \int_{0}^{1} \gamma_{t} d t$. Profit maximization by entrepreneurs in sector $F$ therefore implies that the price of good $F$ equals unit cost:

$$
p_{F} R[1-\gamma(\eta L)]=w=1
$$

Our model captures the positive relationship between the financial system's size and its quality. The equilibrium value $\gamma(\eta L)$ is the fraction of time that a firm is unable to fulfill the need for external finance and thus loses output. ${ }^{6}$ Thus we can think of $1-\gamma(\eta L)$ as the quality of the financial system. This quality depends positively the size of financially intensive sector $\eta$. As the number of entrepreneurs in the $F$ sector increases, the probability of a negative aggregate shock of a given magnitude is lower, thus making liquidation a more unlikely event. The following lemma formalizes this property of financial system's quality.

Lemma 1: the quality of the financial system $\gamma(\eta L)$. The function $\gamma(\eta L)$ is decreasing in $\eta$, with $\lim _{\eta \rightarrow 0} \gamma(\eta L)=\frac{1}{2}$ and $\lim _{\eta \rightarrow \infty} \gamma(\eta L)=0$.

\footnotetext{
${ }^{5}$ Here and in the rest of the paper, we ignore integer constraints on $\eta L$ for simplicity.

${ }^{6}$ In our setup, the value of $\gamma(\eta L)$ will be appreciably greater than zero only if the number of firms $\eta L$ is not too large. Thus, in our model, $L$ should be thought of not as the number of workers, but as the number of large enterprises that the labor force in this economy can potentially staff.
} 
Proof: see Appendix.

\subsection{Autarky Equilibrium}

We can now analyze the equilibrium in the closed economy. The equilibrium production structure is characterized by a single variable, $\eta$, which is the share of the labor force employed in sector $F$. A value of $\eta$ pins down the total production of the two goods, and market clearing implies that consumption equals output:

$$
c_{F}=R[1-\gamma(\eta L)] \eta L
$$

and

$$
c_{A}=(1-\eta) L .
$$

Equations (2) through (6) define the autarky equilibrium. The assumptions we made lead to a simple expression for the allocation of production:

$$
\eta^{A}=\alpha
$$

We can then derive the volume of external finance that occurs in this economy. At each instant $t \in[0,1]$, let $k$ be the number of firms that receive a positive shock, and thus $\eta L-k$ be the number of firms that receive a negative shock. If $k>\eta L-k$, the amount of lending in that instant is $\eta L-k$. If $k<\eta L-k$, the amount of lending in that instant is $k$ : the economy is liquidity-constrained. Thus, the expected value of lending at each $t$, and thus the overall value of lending over the period between $t=0$ and $t=1$ is:

$$
\text { Private Credit }=\sum_{1}^{\frac{\eta L}{2}} k P(k)+\sum_{\frac{\eta L}{2}+1}^{\eta L}(\eta L-k) P(k),
$$

where $k$ is a binomial random variable with probability $\frac{1}{2}$ and the total number of draws $\eta L$. Applying the law of iterated expectations, the expression above simplifies to:

$$
\text { Private Credit }=\frac{1}{2} \eta L
$$

which shows that in this simple model, the amount of external finance is linear in the size of the externally dependent sector.

\subsection{Trade Equilibrium}

Suppose that there are two countries, the North and the South. They are endowed with $L^{N}$ and $L^{S}$ units of labor, respectively, and exhibit a Ricardian productivity difference in the $F$ sector: $R^{N}>R^{S}$. We assume that the parameter values are such that the North is the only country to 
produce the $F$ good in the trade equilibrium. As we will see below, this outcome will obtain as long as the North is large enough, and/or the $F$ good is small enough in the consumption bundle. This means that in order to pin down the trade equilibrium production structure, all we need to solve for is the share of labor force employed in the $F$ sector in the North, $\eta^{N}$. Equilibrium is defined by a version of equation (2) in which $c_{F}$ and $c_{A}$ are now overall world consumption values, equation (4) for a given $\eta^{N}$, and the trade versions of the good market clearing conditions:

$$
c_{F}=R^{N}\left[1-\gamma\left(\eta^{N} L^{N}\right)\right] \eta^{N} L^{N}
$$

and

$$
c_{A}=\left(1-\eta^{N}\right) L^{N}+L^{S} .
$$

These four equations lead to a simple expression for equilibrium allocation of resources:

$$
\eta^{N}=\alpha \frac{L^{N}+L^{S}}{L^{N}}
$$

as long as $\eta^{N} \leq 1$. It is immediate from this expression that this condition will be satisfied if $L^{N}$ is large enough, or $\alpha$ is small enough. For example, if the two goods have an equal share of consumption basket, $\alpha=\frac{1}{2}$, and the two countries have the same factor endowments, $L^{N}=L^{S}, \eta^{N}$ is exactly 1 .

What is happening to private credit? It is clear that there is no longer any borrowing or lending in the South. Furthermore, as $\eta^{S}=0$, the value of $\gamma\left(\eta^{S} L^{S}\right)$ in the South is at the maximum: the quality of the financial system deteriorates as the marginal entrepreneur does not have any opportunity to insure against shocks through external finance. In the North, comparing (7) and (10) it is immediate that there is more borrowing and lending after trade opening: $\eta^{N}>\eta^{A}$. This in turn implies that the quality of the financial system improves as well: $\gamma\left(\eta^{N} L^{N}\right)<\gamma\left(\eta^{A} L^{N}\right)$. As more firms enter the $F$ good production, the fraction of time external finance needs of firms are unfulfilled decreases.

\section{Empirical Methodology}

The main point of the paper is that to the extent financial development is an outcome of supply and demand for external finance, a country's trade patterns will affect its financial development. Countries whose trade specialization implies that they produce and export financially dependent goods will experience a higher level of financial development than countries that produce goods for which it is not important to rely on external finance, all else equal. This is especially true of conventional measures of financial development, such as private credit to GDP, which are equilibrium quantities. In order to demonstrate this point empirically, we must construct a summary measure of how financially dependent is a country's export pattern. 


\subsection{The External Finance Need of Exports}

We start with the standard Rajan and Zingales (1998) classification of industries according to their dependence on external finance. The Rajan and Zingales measure is defined as capital expenditure minus cash flow, divided by capital expenditure, and is constructed based on US firm-level data. We use the version of the variable assembled by Klingebiel, Kroszner, and Laeven (2005), in which industries are classified according to the 3-digit ISIC Revision 2 classification. The Rajan and Zingales external dependence measure is reproduced in Table 1.

We combine this industry-level information with data on the structure of a country's exports to develop a measure of a country's external finance need of exports (hereafter $E F N X$ ) by following the approach of Almeida and Wolfenzon (2005). In particular, we construct the following variable for each country and period of time:

$$
E F N X_{c t}=\sum_{i=1}^{I} \omega_{i c t}^{X} E D_{i},
$$

where $c$ indexes countries, $t$ time periods, $i$ industries, $\omega_{i c t}^{X}$ is the share of exports in sector $i$ in total manufacturing exports from country $c$ in time period $t$, and $E D_{i}$ is the Rajan and Zingales measure of dependence on external finance. Summing up across sectors in each country and year implies that our index is at country level, but potentially varies over time.

Armed with this variable, we would like to estimate the following equation:

$$
F i n \operatorname{Dev}_{c t}=\alpha+\beta E F N X_{c t}+\gamma \mathbf{Z}_{c t}+\delta_{c}+\delta_{t}+\varepsilon_{c t}
$$

The left-hand side variable, FinDev $v_{c t}$ is a measure of a country's level of financial development. We condition on the vector of controls $\mathbf{Z}_{c t}$, country fixed effects $\delta_{c}$, and time fixed effects $\delta_{t}$. Our hypothesis is that the effect of financial content of exports, $E F N X_{c t}$, on financial development is positive $(\beta>0)$.

\subsection{Instrumentation Strategy}

It is immediate that we have an important simultaneity problem: a country's trade pattern is surely influenced by its financial development, as documented by Beck (2003), for instance. Thus, in order to estimate the causal relationship going from trade to financial development, we must develop an instrument for our main right hand side variable, namely the external financing need of exports.

In order to do this, we expand the geography-based approach of Frankel and Romer (1999). These authors constructed predicted trade as a share of GDP by first estimating a gravity regression on bilateral trade volumes between countries using only exogenous geographical explanatory variables, such as bilateral distance, land areas, and populations. From the estimated gravity equation, these 
authors predicted bilateral trade between countries based solely on geographical variables. Then for each country they summed over trade partners to obtain the predicted total trade to GDP, or "natural openness."

Our objective is to find an instrument for a measure of export patterns, not aggregate trade openness. Thus, we must extend the Frankel and Romer approach accordingly. Namely, we apply their methodology to exports at sector level, following di Giovanni, Levchenko, and Ranciere (2005). For each industry $i$ and time $t$, we run the Frankel and Romer regression:

$$
\begin{aligned}
\log X_{i c d t}= & \left.\alpha+\beta_{1} \text { ldist }_{c d}+\beta_{2} \text { lpop }_{c t}+\beta_{3} \text { larea }_{c}+\beta_{4} \text { lpop }_{d t}+\beta_{5} \text { larea }_{d}+\beta_{6} \text { landlocked }_{c d}+13\right) \\
& \beta_{7} \text { border }_{c d}+\beta_{8} \text { border }_{c d} * \text { ldist }_{c d}+\beta_{9} \text { border }_{c d} * \text { pop }_{c t}+\beta_{10} \text { border }_{c d} * \text { area }_{c}+ \\
& \beta_{11} \text { border }_{c d} * \operatorname{pop}_{d t}+\beta_{12} \text { border }_{c d} * \text { area }_{d}+\beta_{13} \text { border }_{c d} * \text { landlocked }_{c d}+\varepsilon_{c d}
\end{aligned}
$$

where $\log X_{i c d t}$ is the $\log$ of exports as a share of GDP in industry $i$, from country $c$ to country $d$, at time $t$. The right-hand side consists of the geographical variables. In particular, ldist $_{c d}$ is the $\log$ of distance between the two countries, defined as distance between the major cities in the two countries, lpop $_{c t}$ is the log of population in year $t$, larea $_{c} \log$ of land area, landlocked $d_{c d}$ takes the value of 0,1 , or 2 depending on whether none, one, or both of the trading countries are landlocked, and border $r_{c d}$ is the dummy variable for common border. The right-hand side of the specification is identical to the one Frankel and Romer (1999) use. Note that we will be estimating a separate gravity equation for each sector and time period. All of the right-hand side variables except population, however, are non-time varying, as would be expected of geographical characteristics. Thus, to the extent that we will observe variation in predicted exports in an industry over time, it will be driven purely by changing estimated coefficients in the equation (13) from period to period.

Having estimated equation (13) for each industry and time period, we then obtain the predicted logarithm of industry $i$ exports to GDP from country $c$ to each of its trading partners indexed by $d, \widehat{\log X}_{i c d t}$. In order to construct the predicted overall industry $i$ exports as a share of GDP from country $c$, we take the exponential of the predicted bilateral log of trade, and sum over the trading partner countries 1 through $C$, exactly as in Frankel and Romer (1999):

$$
\widehat{X}_{i c t}=\sum_{\substack{d=1 \\ d \neq c}}^{C} e^{\widehat{\log X}_{i c d t}} .
$$

That is, predicted total trade as a share of GDP for each industry, country, and time period is the sum of the predicted bilateral trade to GDP over all trading partners. ${ }^{7}$ Thus, we in effect modified and extended the Frankel and Romer methodology in three respects. First, and most importantly,

\footnotetext{
${ }^{7}$ An important question is how to deal with cases of zero bilateral trade. Since we take logs of trade values, our gravity estimation procedure ignores zeros. Thus, we generate predicted values of trade only when the actual value is positive. One interpretation of our procedure is that it "predicts" zero trade when it observes zero trade.
} 
we construct the Frankel and Romer predicted trade measures by industry. Second, we do it over time. And finally, rather than looking at total trade, we look solely at exports.

Armed with a working model for predicting exports to GDP in each industry, it is straightforward to construct the instrument for external financing need of exports, based on predicted export patterns rather than actual ones. That is, our instrument will be, in a manner identical to equation (11):

$$
\widehat{E F N X}_{c t}=\sum_{i=1}^{I} \widehat{\omega}_{i c t}^{X} E D_{i}
$$

Here, the predicted share of exports in industry $i$, in country $c$ and time $t, \widehat{\omega}_{i c t}^{X}$, is constructed from the predicted exports to GDP ratios, $\widehat{X}_{i c t}$ in a straightforward manner:

$$
\widehat{\omega}_{i c t}^{X}=\frac{\widehat{X}_{i c t}}{\sum_{i=1}^{I} \widehat{X}_{i c t}} .
$$

Note that even though $\widehat{X}_{i c t}$ is exports in industry $i$ normalized by a country's GDP, every sector is normalized by the same GDP, and thus they cancel out when we take the predicted export share.

We proceed by describing the data sources in the next section. We provide a snapshot of our data, focusing on the patterns of external financing needs of exports that we obtain. Then, in the following section we document stages of constructing our instrument, and present OLS and 2SLS regression results for both a cross-section of countries and a panel of 5-year averages going back to the 1970 's.

\section{Data Description}

International trade flows come from the World Trade Database described in Feenstra et al. (2005). This database contains bilateral trade flows between some 150 countries, accounting for $98 \%$ of world trade. Trade flows are reported using the 4-digit SITC Revision 2 classification. Since our variable of interest, $E F N X_{c t}$, is constructed using information on total exports from each country in each industry, we first aggregate bilateral flows across countries to obtain total exports for each country and manufacturing sector. We then convert the trade flows from SITC to 3-digit ISIC Revision 2 classification. ${ }^{8}$ This allows us to combine the trade data with the information on external dependence from Rajan and Zingales.

For the purposes of estimating the gravity equation (13), we retain information on bilateral trade, converting it once again into the 3 -digit ISIC Rev. 2 classification. We merge bilateral trade data with geography variables taken from Centre d'Etudes Prospectives et d'Informations Internationales

\footnotetext{
${ }^{8}$ The conversion is based on the concordance found on the International Trade Resources website maintained by Jon D. Haveman: http://www.haveman.org.
} 
(CEPII). The CEPII database contains information on bilateral distances between the major cities for each pair of countries, whether two countries share a border, as well as information on land area and whether a country is landlocked. ${ }^{9}$ Population data is taken from World Bank's World Development Indicators for the period 1970-1999. Exporter and importer population is the only variable in our gravity specification that changes over time.

The data on financial development comes from the database originally compiled by Beck, DemirgucKunt, and Levine (2000). We use a version that has been checked for accuracy by Loayza and Ranciere (2005). Following the standard in the literature, our preferred indicator of financial development is the ratio of credit by banks and other financial institutions to the private sector as a share of GDP ("private credit"). The controls in our estimation include overall trade openness (imports plus exports as a share of GDP) and PPP-adjusted GDP per capita income, both of which come from the Penn World Tables (Heston, Summers and Aten, 2002). Finally, we use information on countries' legal origin as defined by La Porta et al. (1998), extended to include the socialist legal system.

The final sample includes 96 countries, and is an unbalanced panel of 5-year averages from 1970-74 to 1995-99. Appendix Table A1 presents the data on the external financing need of exports, $E F N X_{c t}$, for our sample of countries for the most recent 5-year period, 1995-99. Aside from $E F N X_{c t}$, the table contains information on the top two export sectors, the share of the top two sectors in the overall manufacturing exports, overall trade openness, private credit, as well as the sample means of these variables. It is clear that while there is some correlation between per capita income and the financial content of trade, income is far from a perfect predictor of $E F N X_{c t}$. The top two countries ranked according to the financial content of trade in this period are Malaysia and Philippines, only then followed by Singapore, Japan, and Switzerland. Only the bottom two countries have the financial content of trade that is negative in this period, Malawi and Zimbabwe. In these countries, the main export industry is Tobacco, which has a negative external finance dependence according to the Rajan-Zingales classification.

We plot our estimates of the external finance need of exports against log of PPP-adjusted per capita income in Figure 2. It is clear that while there is a positive relationship between income and our variable of interest, it is far from close. The correlation between the two variables is less than 0.4. Figure 3 plots the external finance need of exports against overall trade openness. There is little relationship between the two variables, and thus, as expected, we are measuring something distinct from trade openness when we construct our measure of the external financing need of exports. Finally, Figure 4 plots financial development against $E F N X_{c t}$. There is a positive relationship

\footnotetext{
${ }^{9}$ The dataset is available online at http://www.cepii.fr/anglaisgraph/bdd/distances.htm.
} 
between the two variables, though it is not extremely close. The correlation coefficient between them is above 0.5, with a Spearman rank correlation of 0.42 in the period 1995-99. We turn to a regression analysis of the relationship between these two variables after presenting the stages of constructing the instrument.

\section{Results}

\subsection{Sector-Level Gravity Estimation}

In order to build the instrument, we estimate equation (13) for each industry and 5-year period between 1970-74 and 1995-99. Because all in all we have to run some 170 regressions, presenting the full regression output would be impractical. Thus, we summarize the results for the most part graphically. In the entire sample of our regressions, the smallest number of observations is 773 , the largest is 6877 , with the mean of 3677 . The R-squared's range from 0.14 to 0.56 , with the mean of 0.32 .

Because the right-hand side variables are the same in all regressions, our empirical strategy would only work if the estimated coefficients differ significantly across sectors. Thus, the first important question we must answer is whether or not there is much variation in the estimated coefficients. Figure 5 plots, for each of the 13 right-hand variables, the range of coefficient estimates across sectors and years. There is clearly quite a bit of dispersion in virtually all of the coefficients. For the period 1995-99 for example, the distance coefficient ranges from -0.8 to 0.04 (though the latter is not significantly different from zero). This variation in gravity coefficients across industries is quite typical of sector-level gravity studies, which have focused for the most part on the distance coefficient (see, among others, Rauch, 1999, Hummels, 2001, Evans, 2003, and Chaney, 2005).

We are also hoping to construct an instrument that varies meaningfully over time. Because none of our regressors except population changes over time, any time variation in the instrument will come from changes in the coefficient estimates for each sector. We check whether our estimates have this feature in Figure 6. It plots, for each sector, the evolution of the coefficient on the log of bilateral distance. Solid dots indicate the point estimates, while hollow dots are the point estimates plus and minus two standard errors. ${ }^{10}$ It is clear that we do have time variation, and its extent varies across sectors. Nonetheless, in almost every sector, among the coefficients for the individual time periods there is a pair that is significantly different from each other. Another notable feature of this Figure is that the changes are not monotonic over time: the distance coefficient within a sector often falls in some periods and rises in others. Distance coefficient changes in gravity models over time have been examined elsewhere in the literature, though the conclusions differ across studies. While some

\footnotetext{
${ }^{10}$ Similar plots for every other coefficient are available upon request.
} 
(e.g. Frankel, Stein, and Wei, 1997, Eichengreen and Erwin, 1998, and Soloaga and Winters, 2001) find the distance coefficient increasing over time for various samples of countries and time periods, others (e.g. Coe et al., 2002, Brun et al., 2005) reach the opposite conclusion. Our strategy does not rely on a particular direction of change in the coefficient: all we require are changes over time, and, preferably, differentially across sectors. Note also that both sector-level and across-time studies of gravity coefficients have been primarily about the coefficient on distance. Our approach exploits sector and time variation in all of our estimated coefficients.

Finally, we use our estimates to generate predicted exports as a share of GDP in each sector, as outlined in Section 3. Using that, we construct the predicted external finance need of exports. Figure 7 plots it against the actual EFNX for the period 1995-99, along with a 45-degree line. We can see that while there is a strong positive relationship between the two, it is not at all one-toone. In particular, our procedure clearly underestimates the external finance need of exports for countries in which it is unusually high, and overestimates it for countries where it is low. This is comforting for us, as it indicates that our approach is not so mechanical that is reproduces the actual values perfectly. Appendix Figure A1 plots the actual and predicted values of $E F N X$ for our entire sample of countries over time. When it comes to time variation in the actual and predicted values of $E F N X$, the picture is broadly similar: the predicted value most of the time follows a similar trend as the actual $E F N X$, though it is usually flatter.

\subsection{Financial Development Results}

\subsubsection{Cross-sectional Specifications}

We start with the cross-sectional OLS regression. We estimate equation (12) using the averages of the left-hand side and all of the controls for the entire time period, 1970-99. ${ }^{11}$ The results are presented in Table 2, with White robust standard errors in parentheses. Column 1 reports the bivariate relationship between financial development and simple trade openness. While trade openness is significant at $10 \%$ level, the relationship is not close, with the R-squared of 0.05 . When instead we use $E F N X_{c}$, as is done in Column 2, the R-squared is 0.28 , and the variable of interest is significant at the $1 \%$ level, with a t-statistic of 4.1. Column 3 includes both the trade openness and the external finance need of exports. The coefficient on $E F N X$ is virtually unchanged. Columns 4 and 5 attempt to control for other determinants of financial development. We first include the legal origin dummies from La Porta et al. (1998), and then per capita income. The latter is meant to capture a country's overall level of development. While in both of these specifications the coefficient on $E F N X_{c}$ is about one third smaller, it nonetheless remains significant at the $1 \%$ level. Finally,

\footnotetext{
${ }^{11}$ Note that since we have an unbalanced panel, our procedure results in averaging over different numbers of years for different countries.
} 
column 5 includes both the legal origin dummies and per capita income on the right-hand side. The coefficient on our variable of interest is further reduced somewhat, but preserves its significance at $1 \%$ level. Note that with all of the controls included in our specification, the adjusted R-squared is 0.63 , only about double the R-squared of the bivariate regression with only $E F N X_{c}$ as the independent variable.

Endogeneity is clearly a first-order issue in our estimation. As has been shown in several empirical studies, a country's level of financial development affects trade patterns, and thus will affect the external finance need of exports as we construct it. We deal with the simultaneity problem by adopting an instrumental variables approach we described in Section 3. We estimate a two-stage least squares (2SLS) regression, using predicted external finance need of exports $\left(\widehat{E F N X_{c}}\right)$ as an instrument for actual $E F N X_{c}$. Table 3 reports the results. The top panel contains the full results of the second stage of the regression, while the bottom panel reports the coefficient on $\widehat{E F N X} \widehat{C}_{c}$ from the first stage. Column 1 reports a bivariate regression with $E F N X_{c}$ on the right-hand side. The 2SLS coefficient is significant at $1 \%$ level. It is about two thirds higher in magnitude than the OLS coefficient. Columns 2 through 5 follow the sequence of Table 2. We first include overall trade openness into the regression, and see that the coefficient of interest is virtually unchanged. Including the legal origin controls reduces the coefficient a bit, while controlling for per capita income lowers it further. In the most stringent specification, which includes openness, legal origin indicators, and per capita income, the coefficient of interest is about half the magnitude of the coefficient in column 1. It is nonetheless highly significant, with the p-value of $2.3 \%$. Examining the bottom panel of the Table, we can see that in the first stage, the coefficient on the predicted external finance need of trade is very close, and slightly above, 1 . The coefficient on $\widehat{E F N X}$ is always significant at the $1 \%$ level.

The results are economically significant but not implausibly large. Using the most conservative coefficient estimates, the OLS results imply that moving from the 25 th to the 75 th percentile in the external finance need of exports raises the ratio of private credit to GDP by roughly 10 percentage points. This is equivalent to about 0.3 of the standard deviation of private credit, or to moving from the 25th to the 50th percentile in the distribution of private credit in our sample. The most conservative 2SLS estimate implies that the same movement in $E F N X_{c}$ leads to a predicted change in private credit over GDP of about 19 percentage points, or 0.56 of a standard deviation of private credit observed in our sample. 


\subsubsection{Panel Specifications}

The cross-sectional results clearly point to an important role of trade in the development of a country's financial system. We would like to go beyond the cross-section, however, and exploit the time series dimension of our data. To this end we estimate the full panel version of equation (12) on a sample of non-overlapping five-year averages of all the variables from 1970-74 to 1995-99. In order to identify our effect from the time variation in the variable of interest, all our specifications include a full set of country and time fixed effects. Furthermore, we cluster the standard errors at country level throughout, to address the problem of time series correlation in our variables (see Bertrand, Duflo, and Mullainathan, 2004). This is the most conservative clustering available to us with this dataset.

Table 4 presents the results. Columns 1 through 4 report the OLS exercise. We first demonstrate, in Column 1, that overall trade openness does not affect financial development when we control for country and time fixed effects. Column 2 reports a specification in which only $E F N X_{c t}$ is included in the regression aside from the battery of fixed effects. The coefficient of interest is significant at $1 \%$ level with the t-statistic of 3.1. Including trade openness, as in Column 3, hardly changes the coefficient. However, when we control for per capita income, the coefficient is reduced by about one third, similarly to the cross-sectional regressions. Nonetheless, it remains significant at the $1 \%$ level. Note that the use of fixed effects results in the adjusted R-squared of between 0.87 and 0.9 , indeed the R-squared of the regression with no independent variables aside from the fixed effects is 0.86 . Thus, while the cross-sectional variation across countries accounts for the overwhelming majority of the variation in financial development, we can still detect the effect of the time variation in the external finance need of exports quite clearly in our regressions.

Columns 5 through 7 report the results of the 2SLS exercise. Once again, we instrument for $E F N X_{c t}$ with predicted $\widehat{E F N X_{c t}}$, the main difference being that now both the actual and the predicted values of the external finance need of exports vary over time. One possible difficulty we face is that all of the gravity regressors in equation (13) aside from population do not vary over time. Thus, to the extent that $\widehat{E F N X_{c t}}$ changes from period to period, it will do so primarily due to changes in the estimated coefficients on the gravity regressors for the various sectors over time. As we discuss above, our gravity coefficients do change over time, giving us variation in predicted $\widehat{E F N X}_{c t}$. Furthermore, to sweep out the country component, we always include the full set of country fixed effects in the first stage regressions, and the standard errors we report are clustered at the country level as well.

The 2SLS results support what we found with OLS. The top panel reports the second stage coefficients. These are generally about one third larger than the OLS coefficients, and significant 
at $5 \%$ level. When we control for per capita income, the t-statistic is 2.17 , with a corresponding p-value of $3.3 \%$. The bottom panel reports the coefficient of interest from the first stage regression. The instrument is highly significant, and the coefficient is quite close to 1, though in contrast to the cross-sectional results, it is lower than 1.

The quantitative effect of our variable of interest as estimated in the panel specifications is similar to the cross-sectional magnitudes. The most conservative OLS coefficient implies that moving from the 25 th to the 75 th percentile of $E F N X_{c t}$ results in an increase in private credit over GDP of 8.2 percentage points, or about 0.22 of a standard deviation of private credit to GDP observed in our data. The 2SLS coefficients imply a change in financial development of 12 percentage points of GDP, or 0.33 standard deviations.

\subsubsection{Robustness}

We check robustness of our results by i) dropping outliers; ii) dropping groups of countries; and iii) using alternative measures of financial development as the dependent variable. Tables 5 and 6 present the results. In both of these Tables, we only report the coefficients and standard errors on $E F N X$, and in each case use the instrumental variables specification with the most stringent set of controls. The top half of each table contains the cross-sectional 2SLS results when controlling for openness, income, and legal origin. The bottom half presents the panel results when controlling for openness and income, country and time fixed effects, and clustering of the standard errors at the country level.

Column 1 of Table 5 reports the results of estimating our equations while dropping the top three and bottom three countries in the distribution of $E F N X$. Compared to the full sample, the estimated coefficients are actually larger and more significant. In order to check whether the results are driven exclusively by the developed countries, the next column estimates our equations on non-OECD countries only. ${ }^{12}$ While the coefficients are somewhat lower, both the cross-section and panel estimates retain their significance level. The economies sometimes called "Asian tigers" have experienced some of the fastest growth of both trade and financial development in the period we are considering. Column 3 excludes the Asian tigers, to check that the results are not driven by these particular countries. ${ }^{13}$ It is clear that the results are not due to Asian tigers. In fact, the coefficient estimates from this subsample are virtually identical to the full sample coefficients. The next two columns drop first the Latin American and Caribbean countries, and then the sub-Saharan African countries. The results are not sensitive to the exclusion of these continents, in fact the estimated

\footnotetext{
${ }^{12}$ OECD countries in our sample are: Australia, Austria, Belgium, Canada, Denmark, Finland, France, Germany, Greece, Iceland, Ireland, Italy, Japan, Netherlands, New Zealand, Norway, Portugal, Spain, Sweden, Switzerland, United Kingdom, and United States. We thus exclude the newer members of the OECD, such as Korea and Mexico.

${ }^{13}$ In our sample, we consider Asian tigers to be: Indonesia, Korea, Malaysia, Philippines, and Thailand.
} 
coefficients are higher and more significant when sub-Saharan Africa is excluded. Finally, because the major oil exporters of the Middle East may occupy a special place in the world trading system, the last column of Table 5 drops these countries, leaving the results once again unchanged. All in all, the panel results are insensitive to the subsample used, as could be expected given that all of our panel specifications include country effects. When it comes to the cross-sectional estimates, we find that all of the subsample coefficients are actually higher than the full sample coefficients, with the exception of the non-OECD sample.

Table 6 presents the results of using alternative measures of financial development. ${ }^{14}$ Colulmn 1 uses the ratio of liquid liabilities to GDP instead of private credit. Both the cross-sectional and panel results are strong, and in the cross-section the significance level actually improves to $1 \%$. Column 2 uses the ratio of stock market value to GDP instead. While the cross-sectional results are significant at the $1 \%$ level, the panel estimates are not. Clearly, to the extent that EFNX explains the differences in the size of countries' stock markets, it does so across countries, and not within countries over time. It is important to note that the sample size is noticeably reduced when we use this measure, especially along the time series dimension. Thus, we simply may not have observations going back far enough in time to make identification off the time series variation. Column 3 presents the results of using the stock market turnover ratio as the dependent variable. It is defined as the value of total shares traded divided by the average real market capitalization. Unlike stock market value to GDP, which is a measure of market size, turnover is a measure of stock market activity. The results we obtain are similar. While the cross-sectional estimate is significant at the $1 \%$ level, we cannot identify the effect from the time series. Finally, we would like to use a measure of the quality of the financial system rather than its size. Column 4 reports the outcome of using the net interest margin as the dependent variable. The net interest margin is defined as the accounting value of banks net interest revenue as a share of its interest-bearing assets. ${ }^{15}$ This variable is available only post-1996, and thus we cannot estimate a panel specification. The cross-sectional 2SLS estimate, however, is significant at the $5 \%$ level, suggesting that there may be an effect on the quality of the financial system as well as its size.

\section{Conclusion}

It is often argued that institutional quality in general and financial development in particular are shaped largely by exogenous events in the past. It is then natural to think of the financial system as an endowment, and therefore differences in financial development as sources of comparative advan-

\footnotetext{
${ }^{14}$ All of the alternative measures come from the most recent version of the Beck, Demirguc-Kunt, and Levine (2000) database.

${ }^{15}$ Unlike all of the other measures, a low value of net interest margin indicates a high quality of the financial system.
} 
tage in trade. This paper takes a different view by asking instead: will trade patterns in turn affect countries' financial development? This is an important question. There is a great deal of evidence that financial development is a key determinant of economic growth (see Levine, 2005, for a survey). On the other hand, the debate about the effect of trade on growth is far from settled. ${ }^{16}$ This paper demonstrates that trade affects financial development directly, a channel for the relationship between trade and growth which has not previously been explored.

We first illustrate our main idea by building a model in which financial development - both the financial system size and its quality - is determined by demand for external finance in production. After trade opening, the country which produces and exports financially dependent goods experiences financial deepening, as demand for external finance inside that country increases. On the other hand, the country which imports financially dependent goods will see its financial system deteriorate, making access to finance more difficult for domestic firms.

We then demonstrate this effect empirically by constructing a measure of a country's external finance need of exports, and relating it to financial development in a large panel of countries. The magnitude of the effect we obtain is appreciable, but not very large. Thus, we do not conclude from our exercise that trade volumes or trade patterns are the primary determinant of financial development. Admittedly, other variables, such as history, legal systems, institutions, openness to capital flows, or the overall level of development are other significant determinants. Another important caveat when it comes to interpretation is that our measure of external finance need of exports is positive except in very rare cases. Thus, our empirical results do not imply that trade has a negative effect on private credit. Rather, what we show is that the demand for external finance coming from exports differs a great deal across countries, and has an appreciable impact on observed levels of financial development.

\section{Appendix}

Proof of Lemma 1:

$\gamma^{t}$ is a random variable with the following probability distribution:

$$
\gamma^{t}= \begin{cases}0 & \text { with probability } \frac{1}{2^{\eta L}} \sum_{k=0}^{\operatorname{Int}\left(\frac{\eta L+1}{2}\right)}\left(\begin{array}{c}
\eta L \\
k
\end{array}\right) \\
1-\frac{2 k}{\eta L} & \text { with probability } \frac{1}{2^{\eta L}}\left(\begin{array}{c}
\eta L \\
k
\end{array}\right) \text { for } 0 \leq k \leq \operatorname{Int}\left(\frac{\eta L-1}{2}\right)\end{cases}
$$

and this implies that

$$
\gamma(\eta L) \equiv E\left(\gamma^{t}\right)=\frac{1}{2^{\eta L}}\left(\begin{array}{c}
\eta L-1 \\
\operatorname{Int}\left(\frac{\eta L-1}{2}\right)
\end{array}\right)
$$

\footnotetext{
${ }^{16}$ Recent papers that argue for a positive impact of trade on growth include, but are not limited to, Frankel and Romer (1999) and Alcala and Ciccone (2004). For the opposing view, see Rodrik and Rodriguez (2000), Rodrik, Subramanian, and Trebbi (2004), and Rigobon and Rodrik (2004).
} 
and it is easy to check that $\gamma(1)=1 / 2$ and $\lim _{\eta \rightarrow \infty} \gamma(\eta L)=0$.

\section{References}

1. Acemoglu, Daron, Simon Johnson, and James Robinson (2001) "The Colonial Origins of Comparative Development," The American Economic Review, 91, 1369-401.

2. Acemoglu, Daron, and Fabrizio Zilibotti (1999) "Information Accumulation in Development," Journal of Economic Growth, 4, 5-38.

3. Alcalá, Francisco and Antonio Ciccone (2004) "Trade and Productivity," Quarterly Journal of Economics 119, 613-46.

4. Almeida, Heitor and Daniel Wolfenzon (2005), "The Effect of External Finance on the Equilibrium Allocation of Capital ," Journal of Financial Economics 75, 133-164.

5. Baldwin, Richard (1989) "Exporting the capital markets:Comparative advantage and capital market imperfections." In: Audretsch, D., Sleuwaegen, L., Yamawaki, H. (Eds.), The Convergence of International and Domestic Markets. North-Holland, Amsterdam.

6. Beck, Thorsten (2002) "Financial Development and International Trade. Is There a Link?" Journal of International Economics, 57, 107-131.

7. Beck, Thorsten (2003) "Financial dependence and international trade," Review of International Economics, 11, 296-316.

8. Beck, Thorsten, Asli Demirguc-Kunt, and Ross Levine (2000) "A New Database on Financial Development and Structure" World Bank Economic Review, September 2000, 597-605.

9. Becker, Bo, and David Greenberg (2003) "The Real Effects of Finance: Evidence from Exports," mimeo, University of Chicago.

10. Bertrand, Marianne, Esther Duflo, and Sendhil Mullainathan (2004) "How Much Should We Trust Differences-in-Differences Estimates?," Quarterly Journal of Economics, 119, 249-75.

11. Braun, Matias, and Claudio Raddatz (2005) "Trade Liberalization and the Politics of Financial Development," World Bank Working Paper 3517.

12. Broner, Fernando and Jaume Ventura "Globalization and Risk Sharing," mimeo, CREI-UPF.

13. Brun, Jean-Francois, Celine Carrere, Patrick Guillaumont, and Jaime de Melo (2005) "Has Distance Died? Evidence from a Panel Gravity Model," World Bank Economic Review 19, 99-120. 
14. Chaney, Thomas (2005) "Distorted Gravity: Heterogeneous Firms, Market Structure, and the Geography of International Trade," mimeo, University of Chicago.

15. Coe, David, Arvind Subramanian, and Natalia Tamirisa, with Rikhil Bhavnani (2002) "The Missing Globalization Puzzle," IMF Working Paper 02-171.

16. Demirguc-Kunt, Asli, and Ross Levine (2001) "Financial Structure and Economic Growth: A Cross-Country Comparison of Bank, Markets, and Development," Cambridge, MA: MIT Press.

17. di Giovanni, Julian, Andrei Levchenko, and Romain Ranciere (2005) "Trade and Growth at Industry Level," unpublished.

18. Do, Quy-Toan, and Andrei Levchenko (2004) "Trade and Financial Development", World Bank Working Paper 3347.

19. Eichengreen, Barry, and D.A. Irwin (1998) "The Role of HIstory in Bilateral Trade Flows," in Jeffrey Frankel (ed.), The Regionalization of the World Economy, Chicago: University of Chicago Press.

20. Evans, Carolyn (2003) "The Economic Significance of National Border Effects," The American Economic Review, 93(4), 1291-1312.

21. Feenstra, Robert C., Robert E. Lipsey, Haiyan Deng, Alyson C. Ma, and Hengyong Mo (2005) "World Trade Flows: 1962-2000," NBER Working Paper No. 11040.

22. Frankel, Jeffrey, and David Romer (1999) "Does Trade Cause Growth?" American Economic Review, 89, 379-399.

23. Frankel, Jeffrey, with Ernesto Stein, and Shang-Jin Wei (1997) "Regional Trading Blocs in the World Economic System," Washington DC: Institute of International Economics.

24. Heston, Alan, Robert Summers, and Bettina Aten, (2002) "Penn World Table Version 6.1," Center for International Comparisons at the University of Pennsylvania (CICUP).

25. Hummels, David (2001) "Towards a Geography of Trade Costs," mimeo Purdue University.

26. Ju, Jiandong, and Shang-Jin Wei (2005) "Endowment versus Finance: A Wooden Barrel Theory of International Trade," IMF Working Paper No. 05/123.

27. Kletzer, Kenneth, and Pranab Bardhan (1987) "Credit markets and patterns of international trade." Journal of Development Economics, 27, 57-70. 
28. Klingebiel, Daniela, Randall Kroszner, and Luc Laeven (2005) "Financial Crises, Financial Dependence, and Industry Growth," World Bank Working Paper 2855.

29. La Porta, Rafael, Florencio Lopez-de-Silanes, Andrei Shleifer, and Robert Vishny (1998) "Law and Finance," Journal of Political Economy, 106, 1113-1155.

30. Levine, Ross (2005) "Finance and Growth: Theory and Evidence," in Philippe Aghion and Steven Durlauf, eds. Handbook of Economic Growth. The Netherlands: Elsevier Science.

31. Levine, Ross and Sergio Schmukler (2005) "Internationalization and Stock Market Liquidity," NBER Working Paper 11894.

32. Loayza, Norman, and Romain Ranciere (2005) "Financial Development, Financial Fragility, and Growth," forthcoming, Journal of Money, Credit, and Banking.

33. Manova, Kalina (2005) "Credit Constraints in Trade: Financial development and export composition," mimeo, Harvard University.

34. Newbery, David, and Joseph Stiglitz (1984) "Pareto inferior trade," Review of Economic Studies, $51,1-12$.

35. Rajan, Raghuram, and Luigi Zingales (1998) "Financial dependence and growth," American Economic Review, 88, 559-586.

36. Rajan, Raghuram, and Luigi Zingales (2003) "The great reversals: the politics of financial development in the 20th Century," Journal of Financial Economics, 69, 5-50.

37. Rauch, James E., 1999, "Networks versus Markets in International Trade," Journal of International Economics, 48, 7-35.

38. Rigobon, Roberto, and Dani Rodrik (2004) "Rule of Law, Democracy, Openness, and Income: Estimating the Interrelationships," forthcoming, Economics of Transition.

39. Rodriguez, Francisco, and Dani Rodrik (2000) "Trade Policy and Economic Growth: A Skeptic's Guide to the Cross-National Evidence," (with Francisco Rodríguez), Macroeconomics Annual 2000, eds. Ben Bernanke and Kenneth S. Rogoff, MIT Press for NBER, Cambridge, MA.

40. Rodrik, Dani (1998) "Why Do More Open Economies Have Bigger Governments?" Journal of Political Economy, 106, 997-1032. 
41. Rodrik, Dani, Arvind Subramanian and Francesco Trebbi (2004) "Institutions Rule: The Primacy of Institutions over Geography and Integration in Economic Development," Journal of Economic Growth, 9, 131-165.

42. Soloaga, Isidro and L. Alan Winters (2001) "Regionalism in the nineties: What effect on trade?" North American Journal of Economics and Finance, 12, 1-29.

43. Svaleryd, Helena, and Jonas Vlachos (2002) "Markets for risk and openness to trade: how are they related?" Journal of International Economics, 57, 369-395

44. Svaleryd, Helena, and Jonas Vlachos (2005) "Financial markets, the pattern of industrial specialization and comparative advantage: Evidence from OECD countries," European Economic Review, 49, 113-144. 
Figure 1: Financial Development and Trade Volumes, 1970-1999.

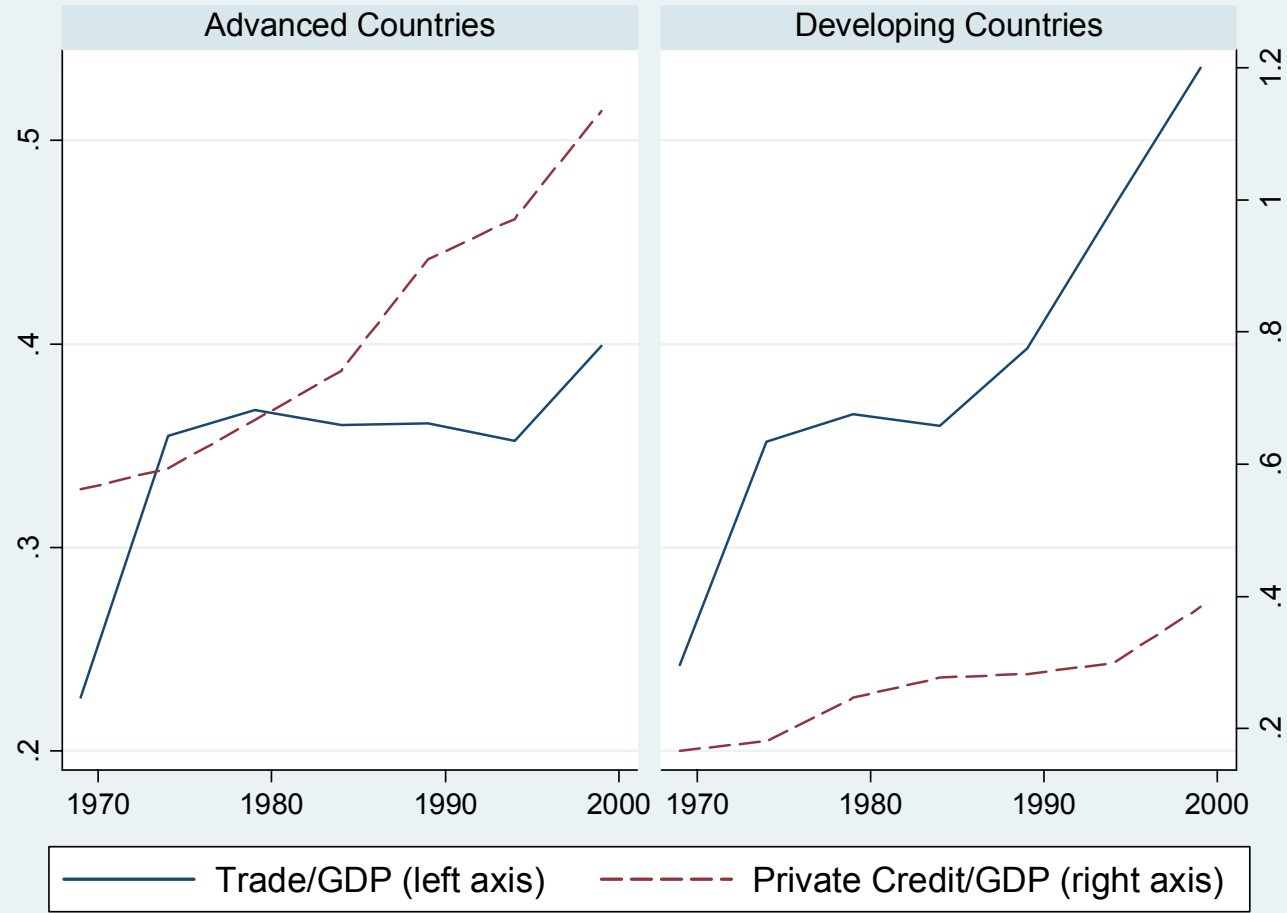

Figure 2: External Finance Need of Exports and Per Capita Income, 1995-99.

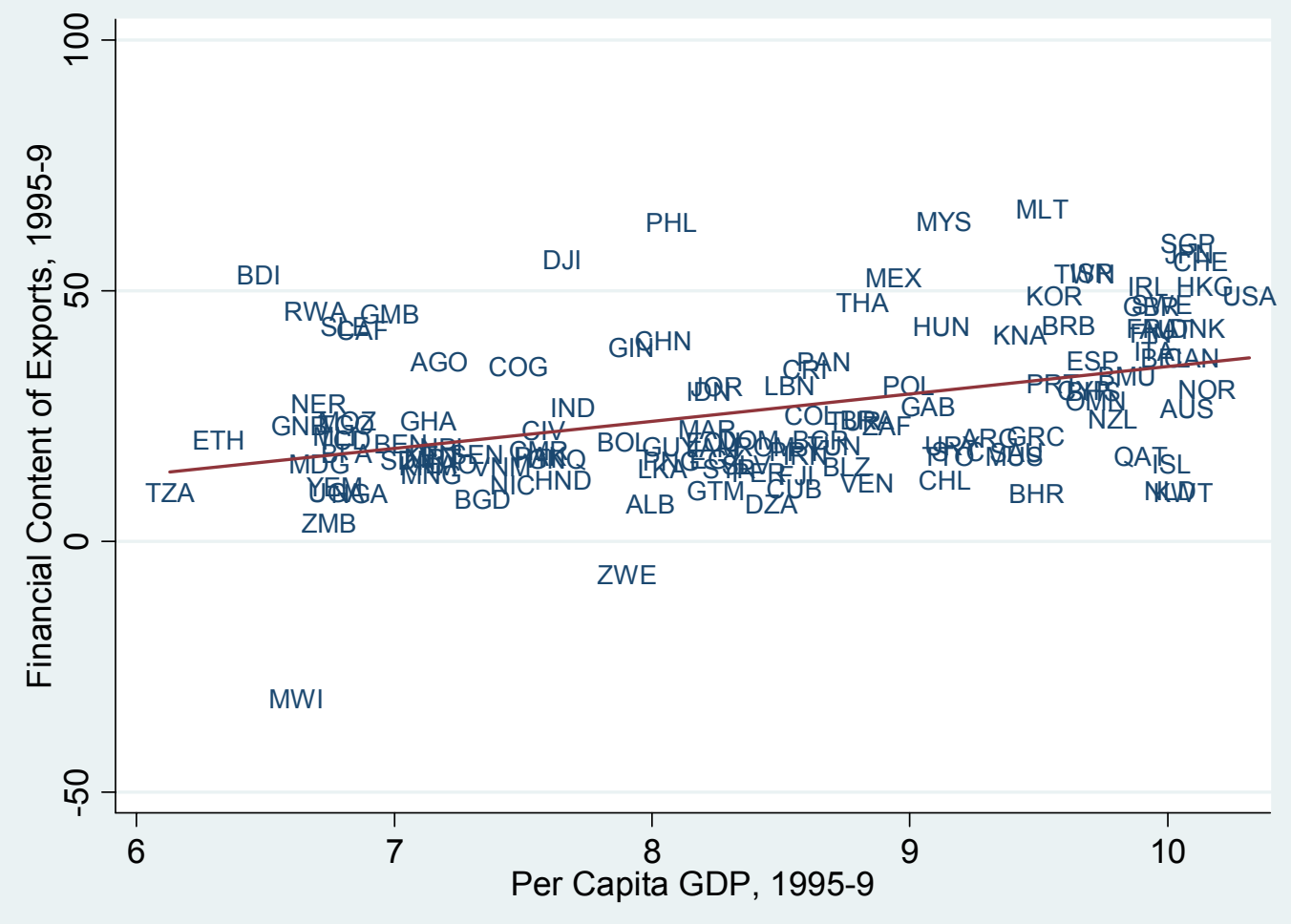


Figure 3: External Finance Need of Exports and Trade Openness, 1995-99.

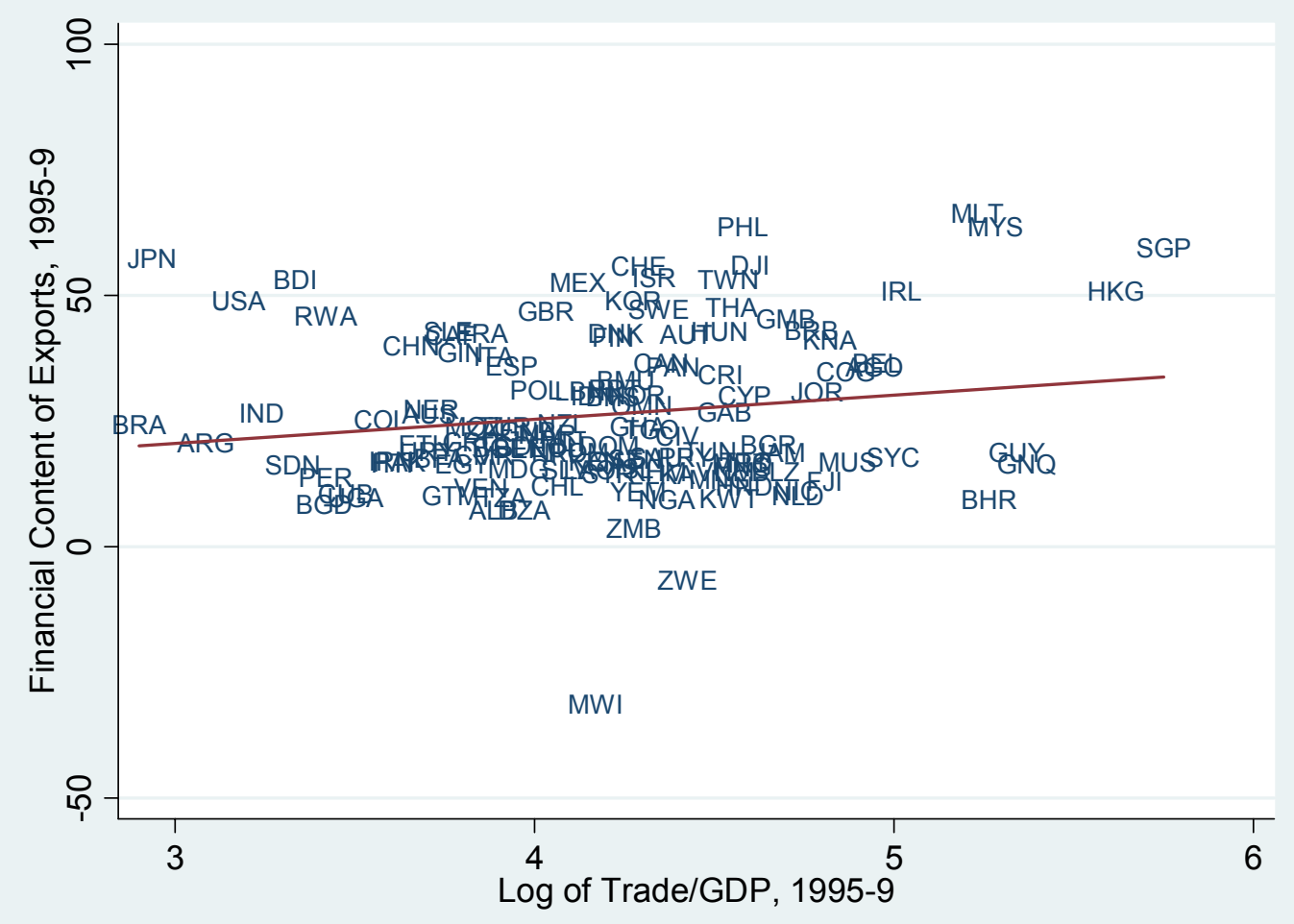

Figure 4: Financial Development and External Finance Need of Exports, 1995-99.

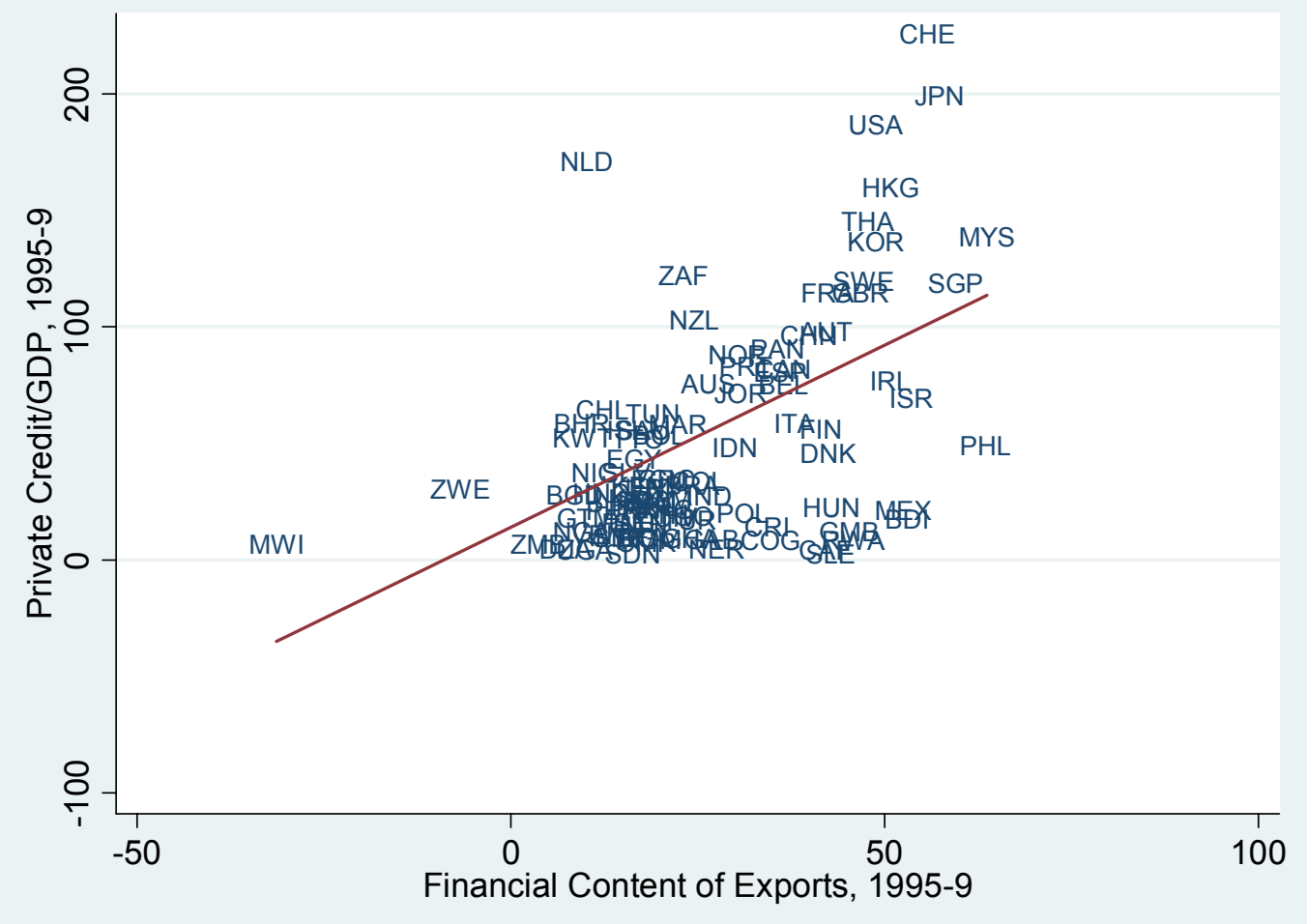


Figure 5: Estimated Sector-Level Gravity Model Coefficients, 1970-99.
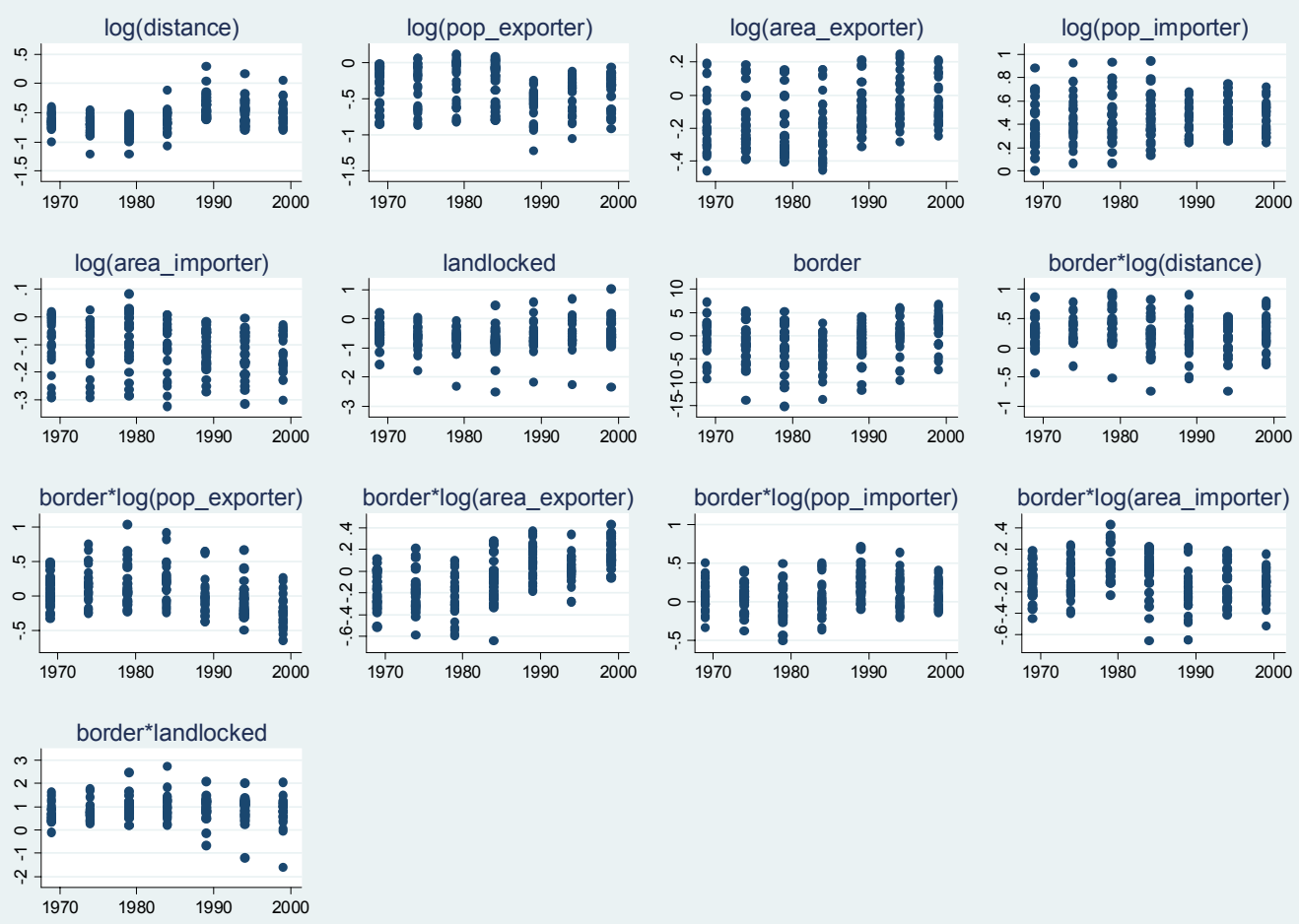

Figure 6: Estimates and Two-Standard Error Bands for the Distance Coefficient, by Sector and over Time.

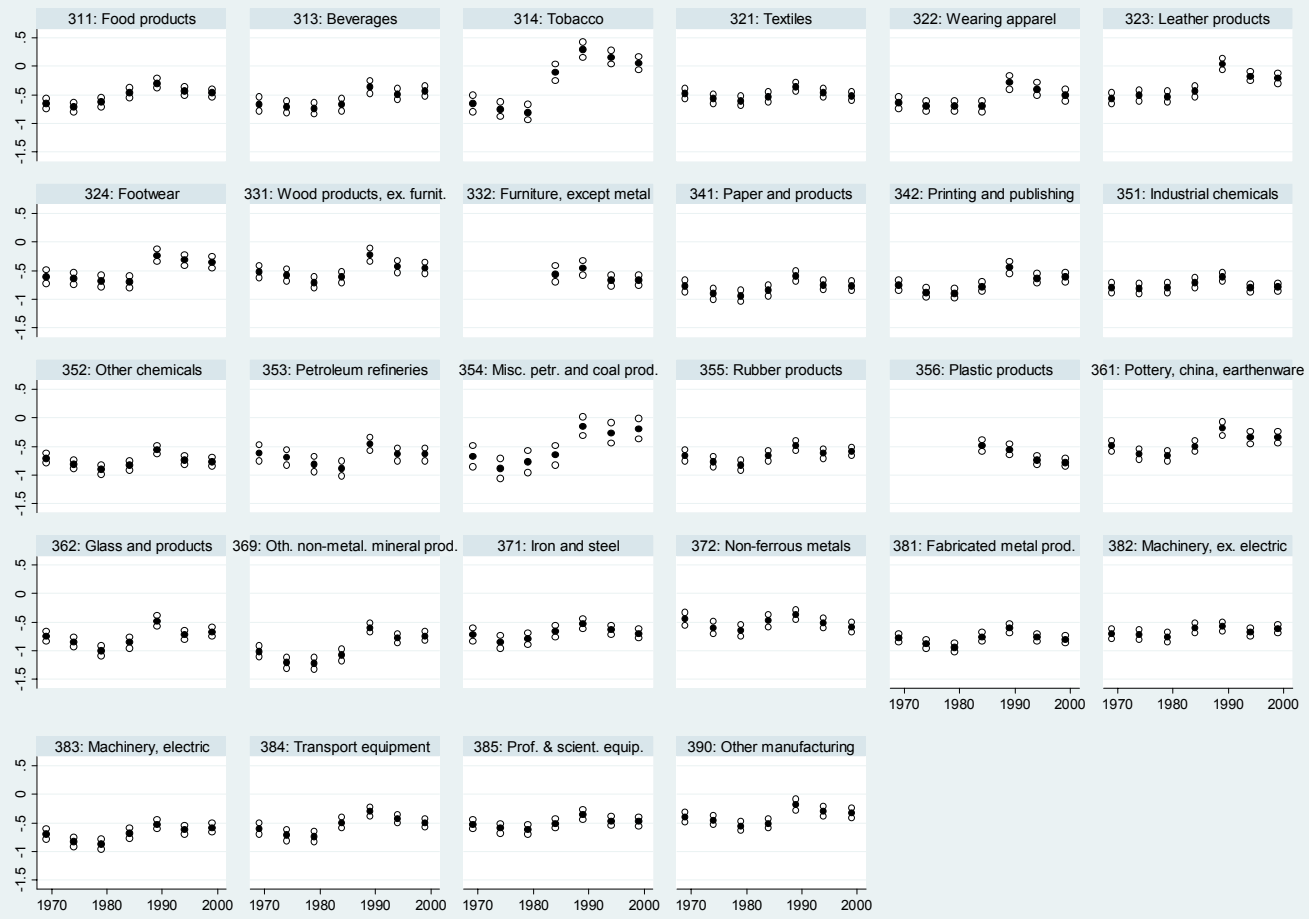


Figure 7: Actual and Predicted External Finance Need of Exports, Average 1970-99

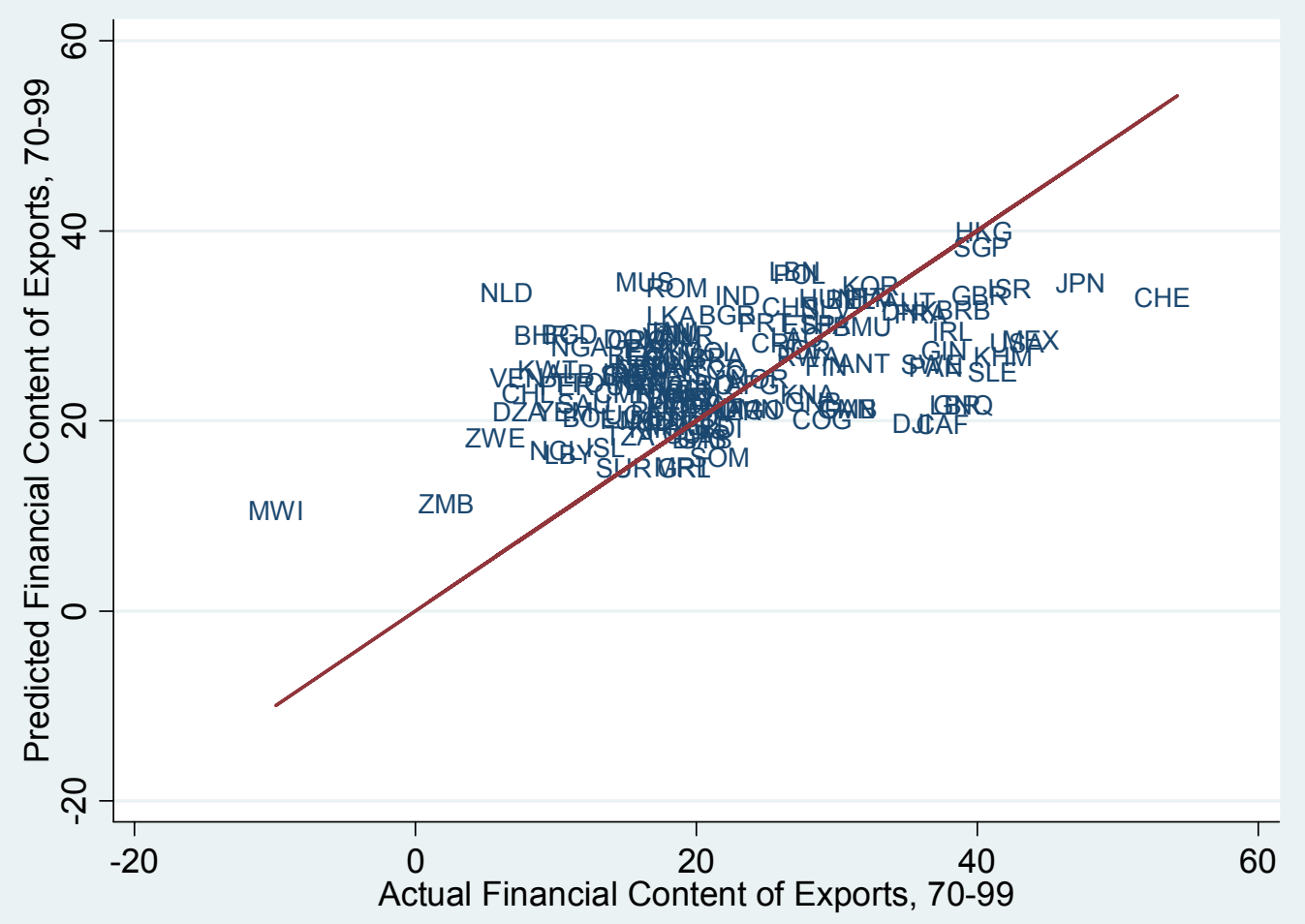


Table 1: The Rajan and Zingales Measure of External Dependence

\begin{tabular}{|c|c|c|}
\hline ISIC code & Industrial sector & External dependence \\
\hline 311 & Food products & 0.14 \\
\hline 313 & Beverages & 0.08 \\
\hline 314 & Tobacco & -0.45 \\
\hline 321 & Textile & 0.19 \\
\hline 322 & Apparel & 0.03 \\
\hline 323 & Leather & -0.14 \\
\hline 324 & Footwear & -0.08 \\
\hline 331 & Wood products & 0.28 \\
\hline 332 & Furniture & 0.24 \\
\hline 341 & Paper and products & 0.17 \\
\hline 342 & Printing and publishing & 0.2 \\
\hline 351 & Industrial chemicals & 0.25 \\
\hline 352 & Other chemicals & 0.75 \\
\hline 353 & Petroleum refineries & 0.04 \\
\hline 354 & Petroleum and coal products & 0.33 \\
\hline 355 & Rubber products & 0.23 \\
\hline 356 & Plastic products & 1.14 \\
\hline 361 & Pottery & -0.15 \\
\hline 362 & Glass & 0.53 \\
\hline 369 & Nonmetal products & 0.06 \\
\hline 371 & Iron and steel & 0.09 \\
\hline 372 & Nonferrous metal & 0.01 \\
\hline 381 & Metal products & 0.24 \\
\hline 382 & Machinery & 0.6 \\
\hline 383 & Electric machinery & 0.95 \\
\hline 384 & Transportation equipment & 0.36 \\
\hline 385 & Professional goods & 0.96 \\
\hline 390 & Other industries & 0.47 \\
\hline
\end{tabular}

Source: Klingebiel, Kroszner, and Laeven (2005). External dependence is defined as capital expenditure minus cash flow, divided by capital expenditure, and is constructed based on US firm-level data. 


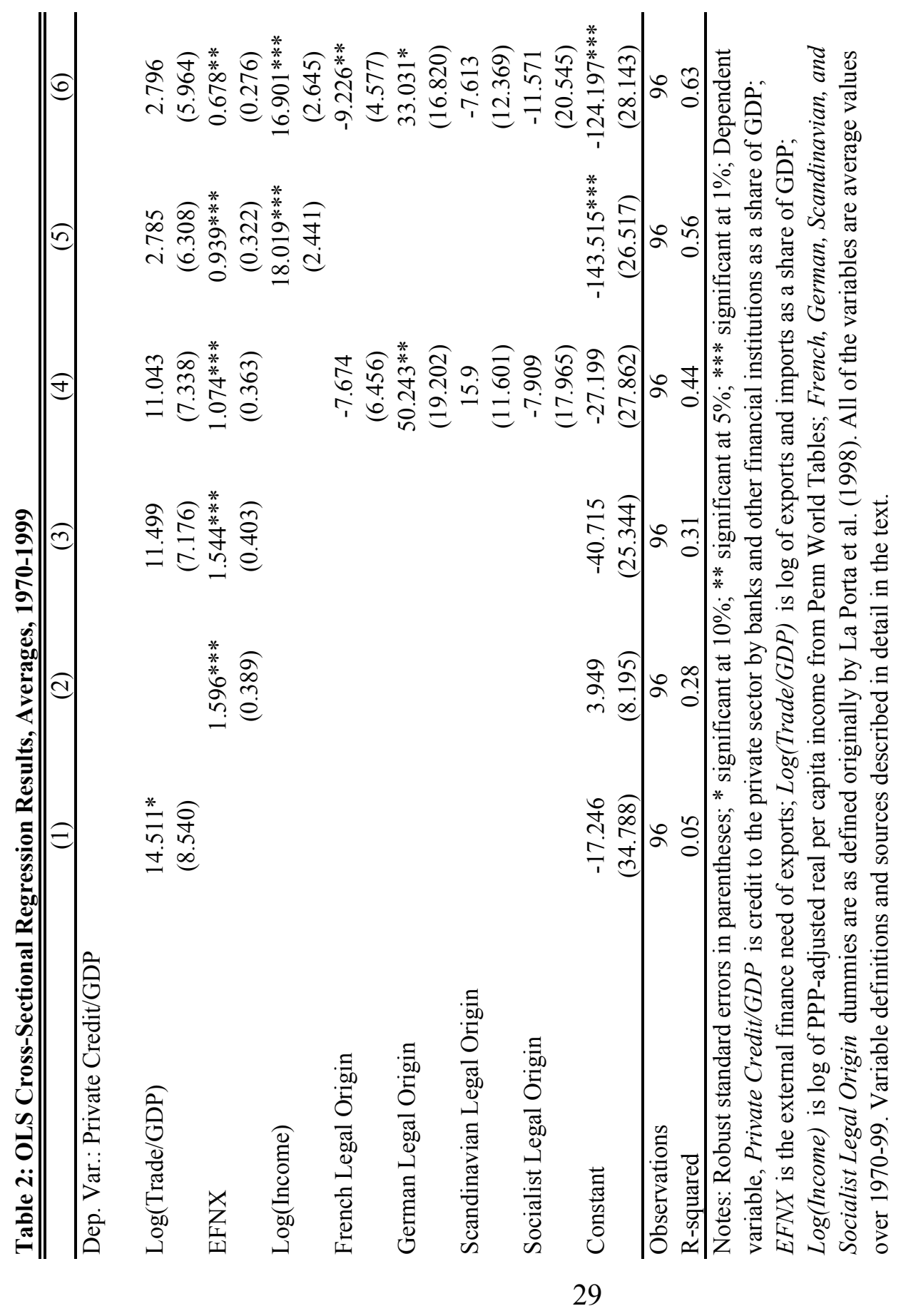




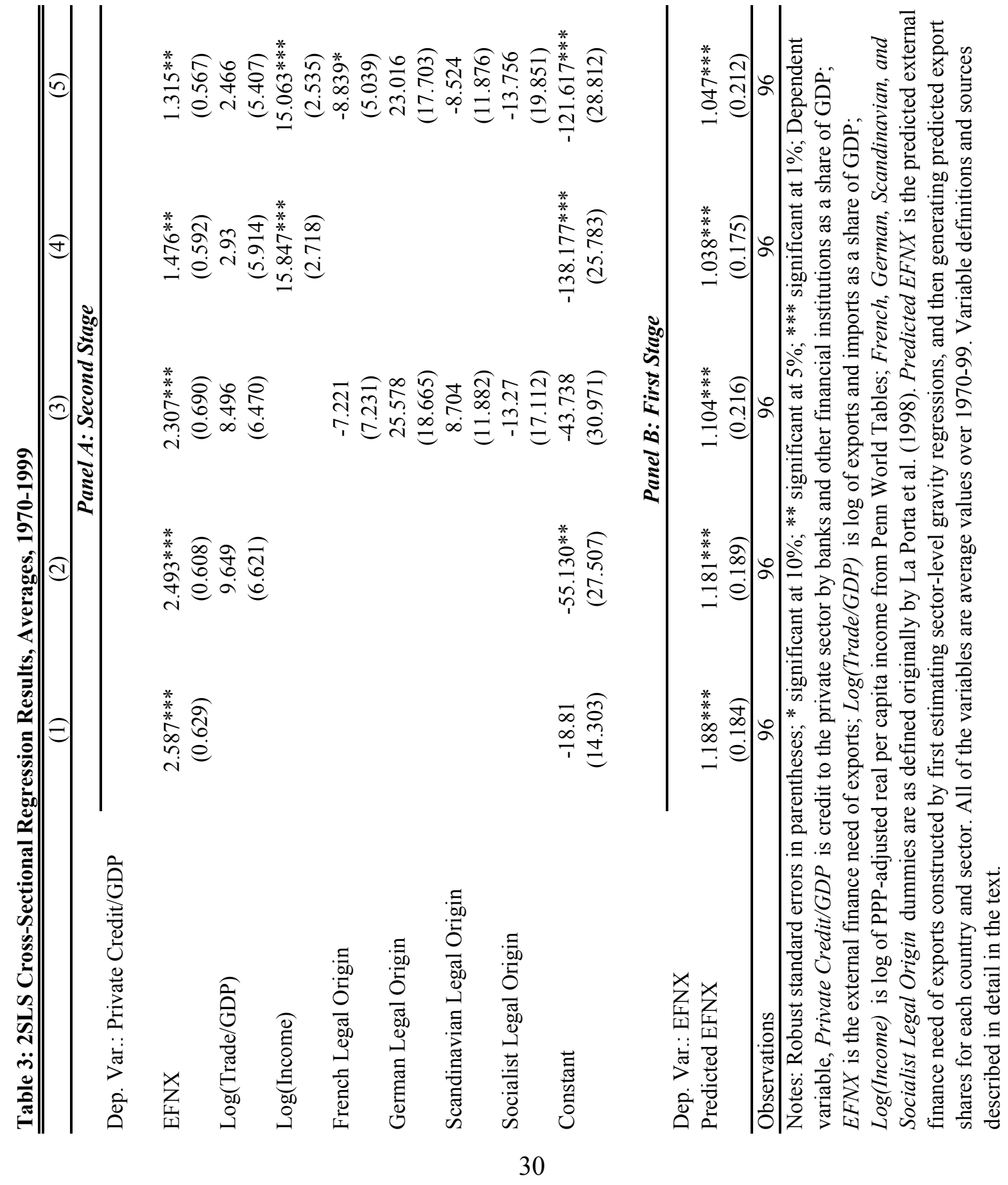




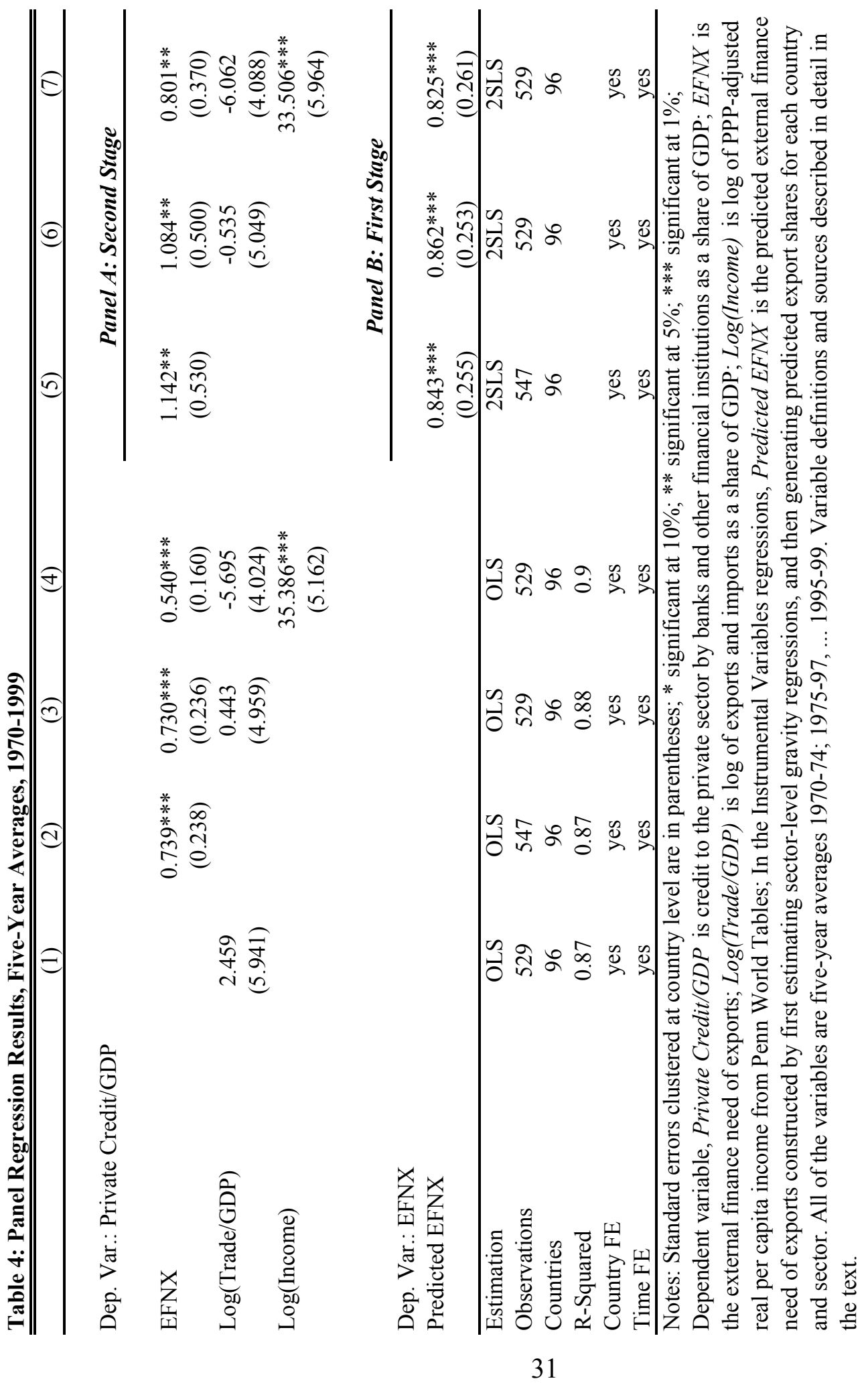




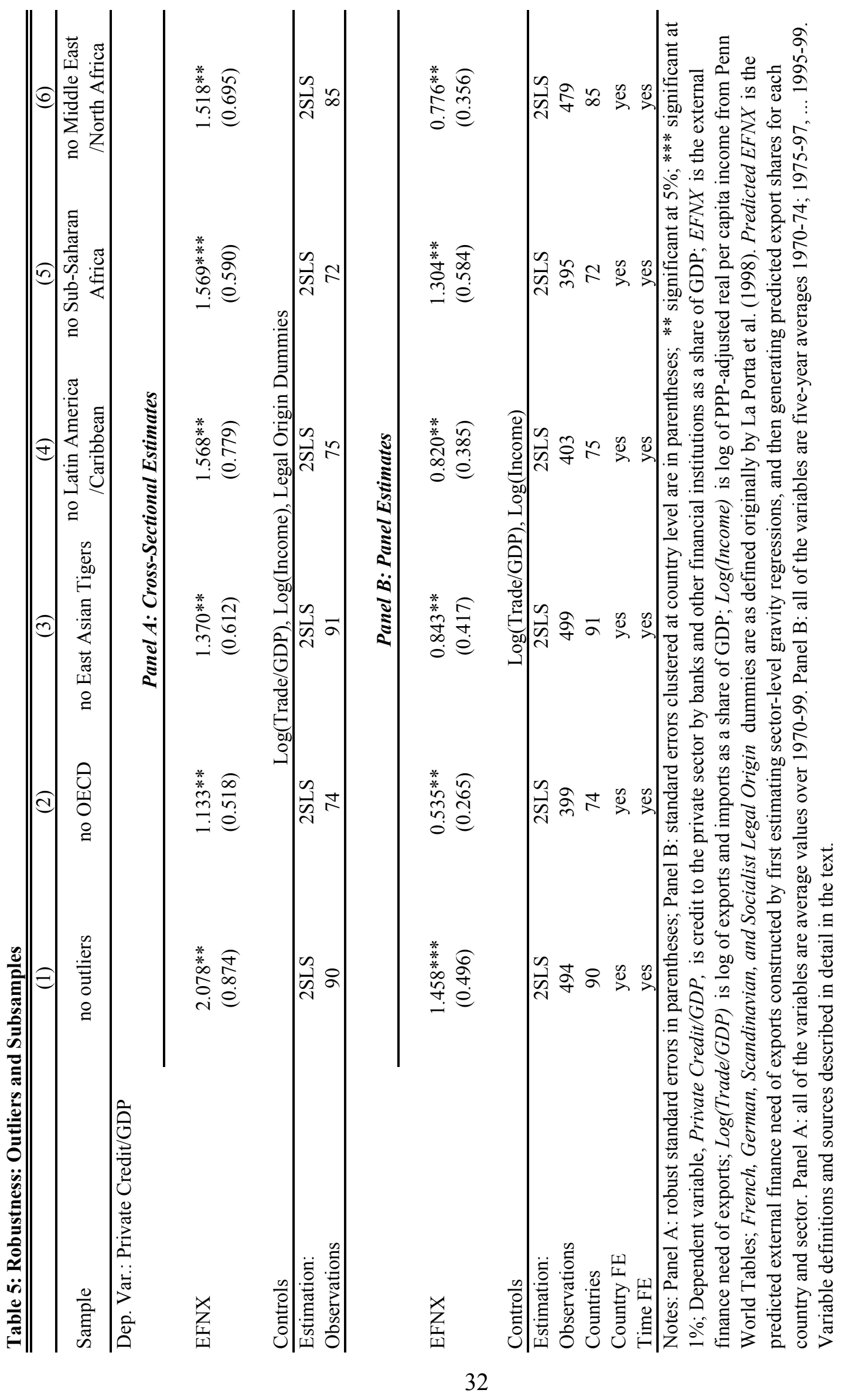




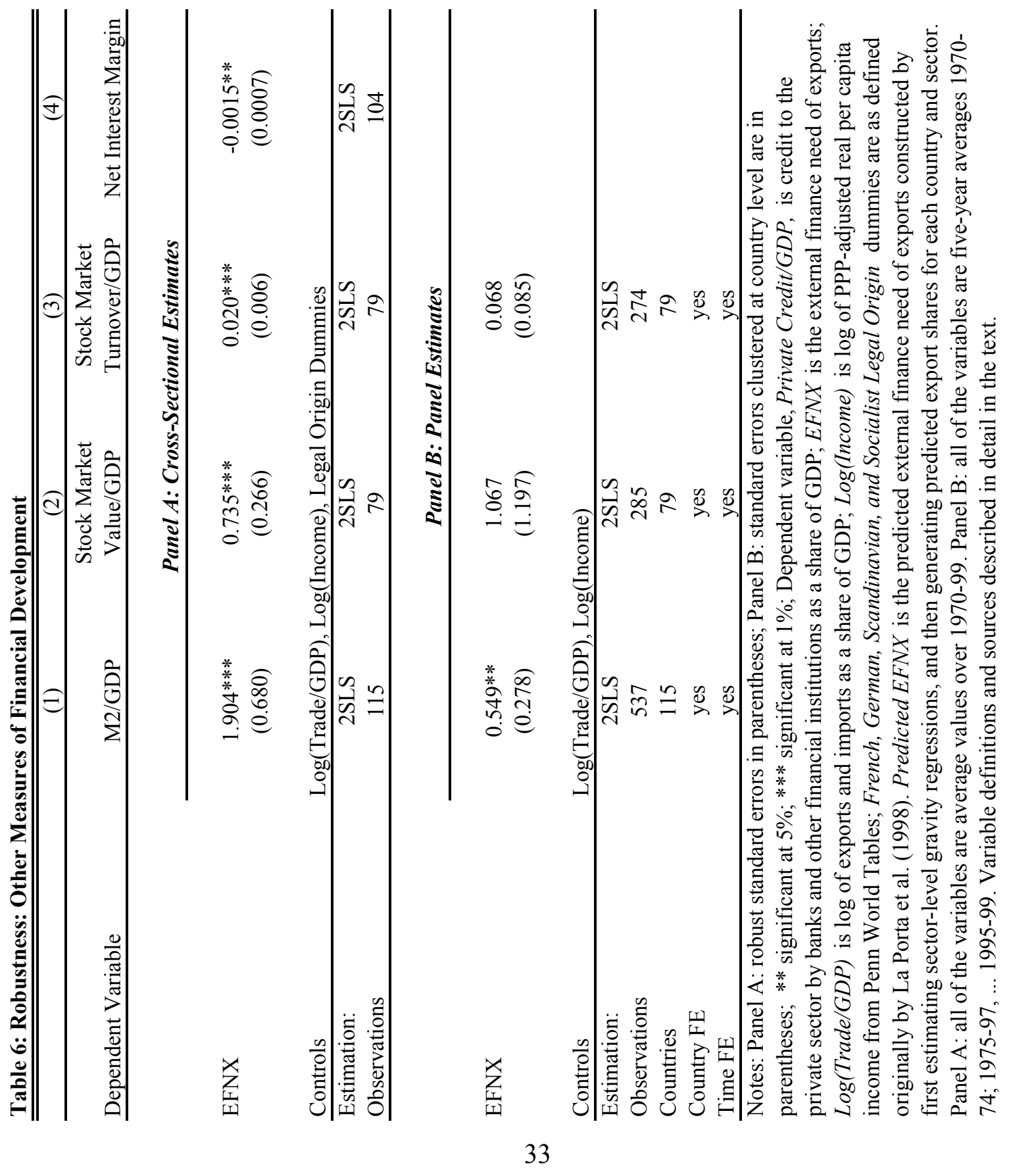




\section{Appendix Figure A1: Actual and Predicted External Finance Need of Exports, by Country and Time Period}
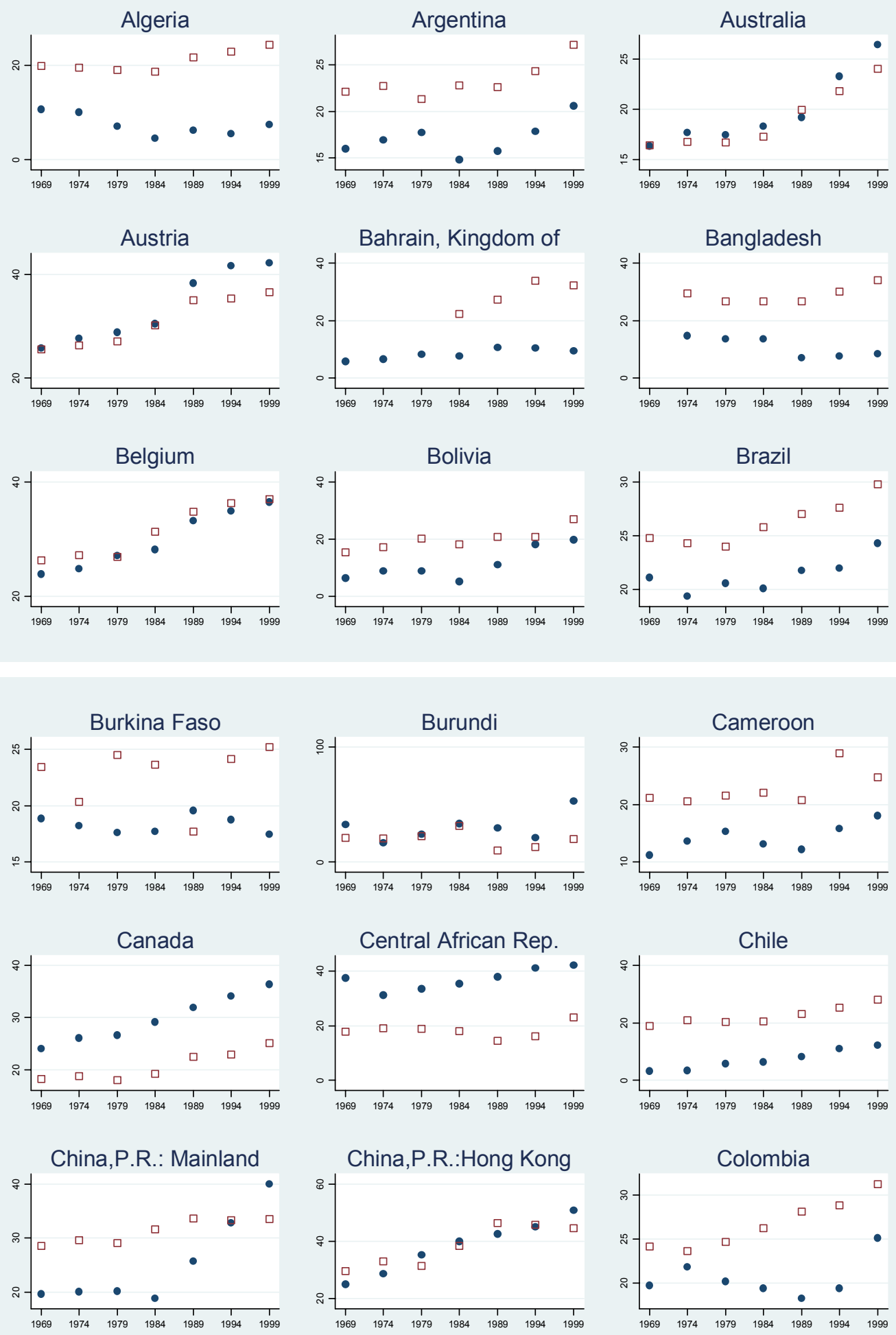

Legend: •: Actual EFNX; $\square$ : Predicted EFNX 

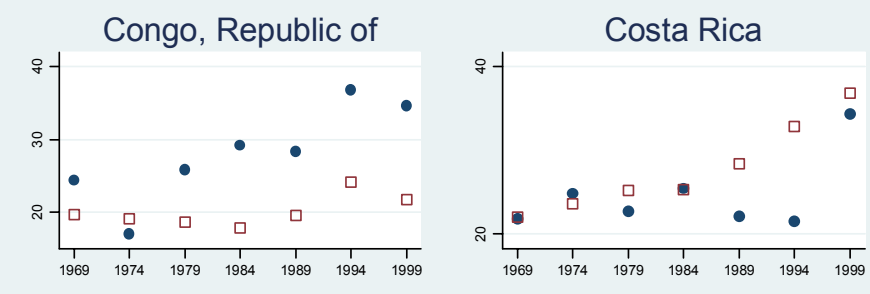

Côte d'Ivoire
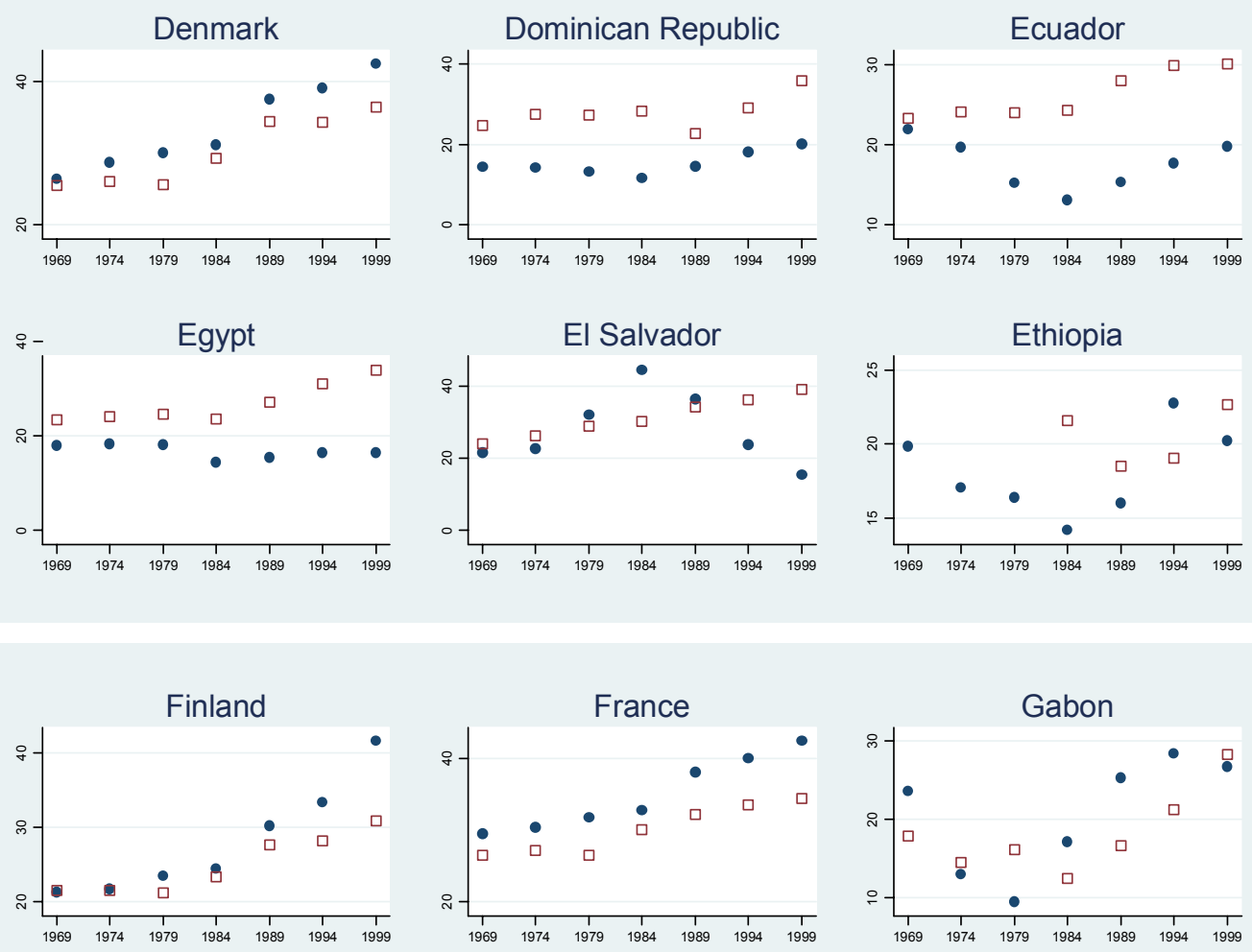

Gabon
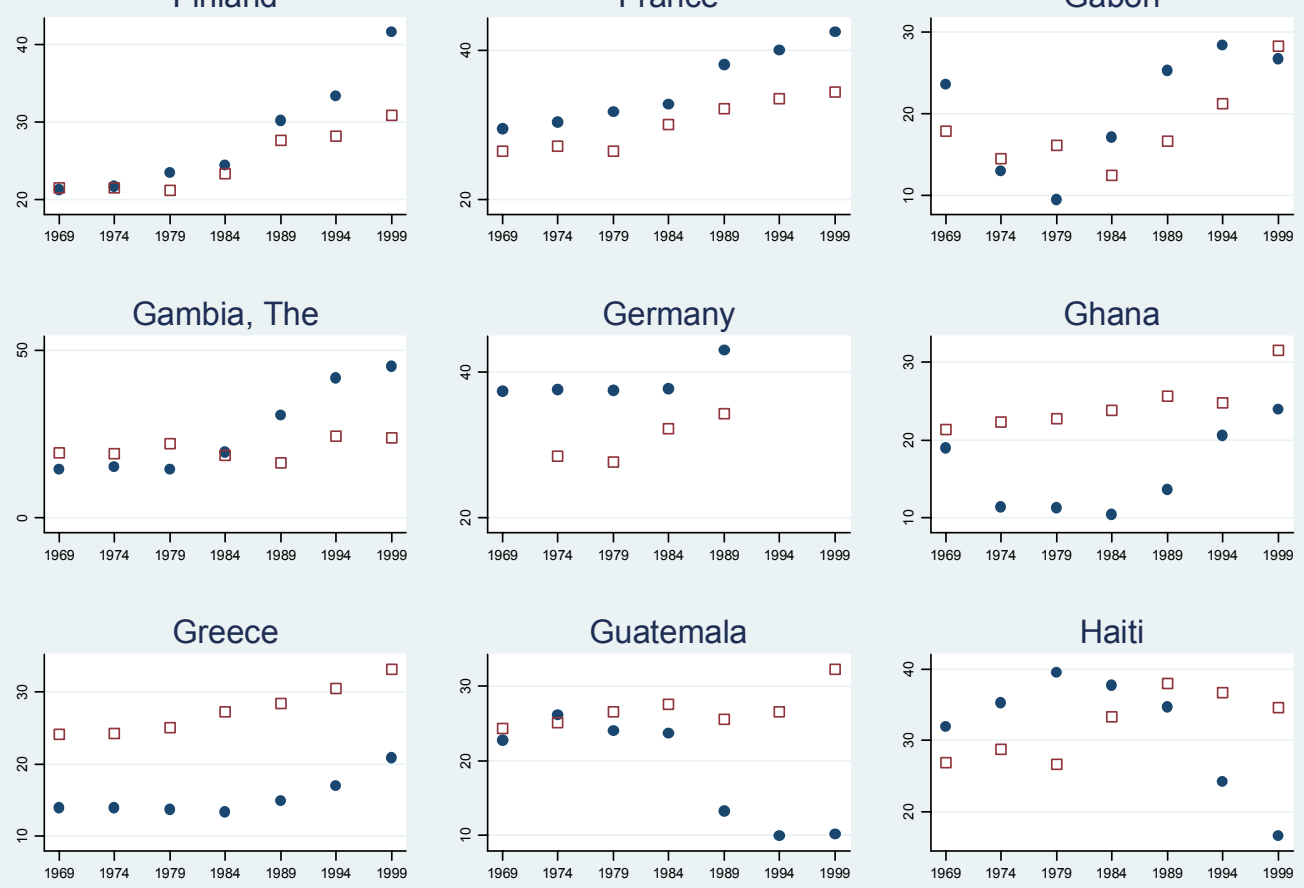

Legend: •: Actual EFNX; $\square$ : Predicted EFNX 

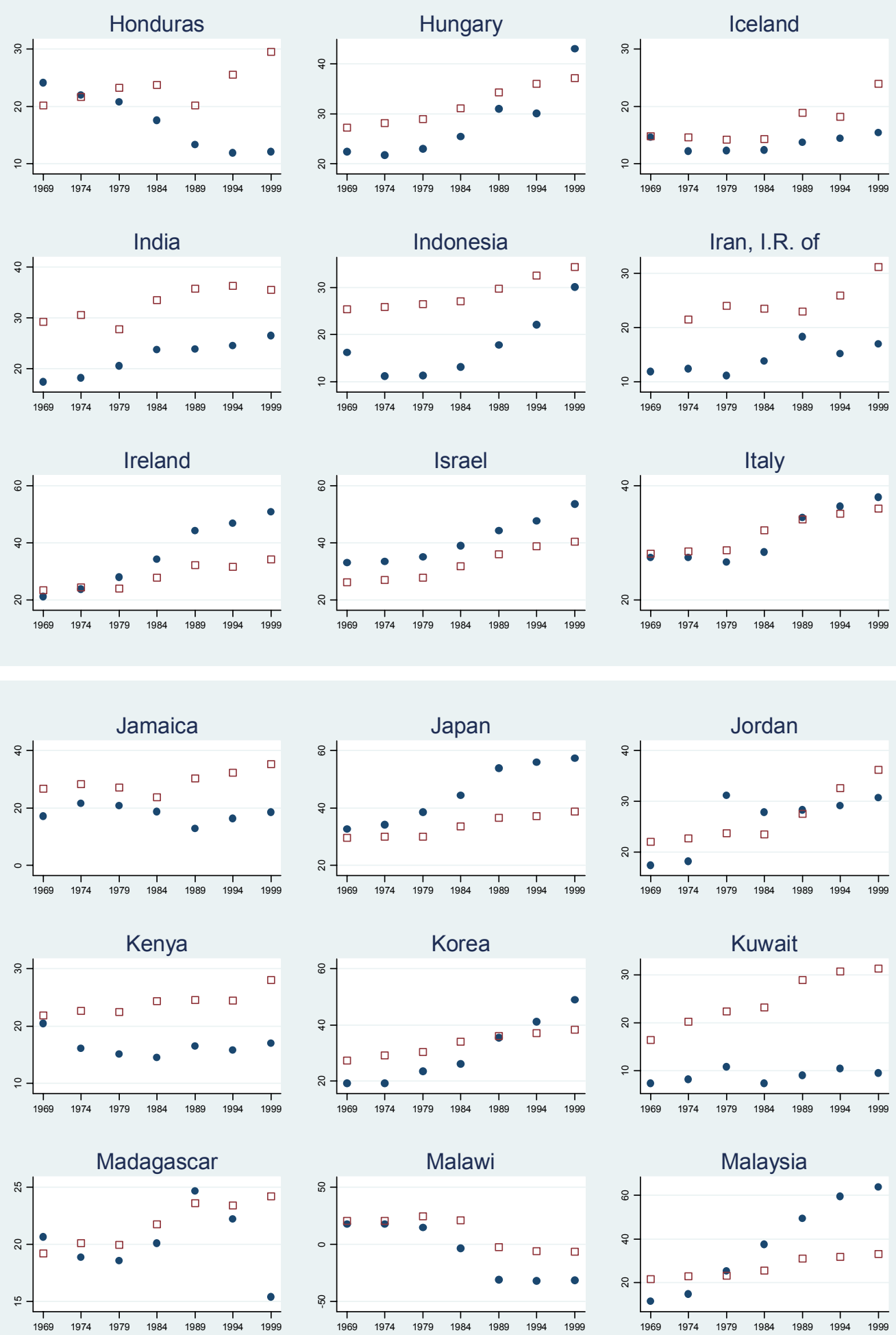

\section{Legend: •: Actual EFNX; $\square$ : Predicted EFNX}



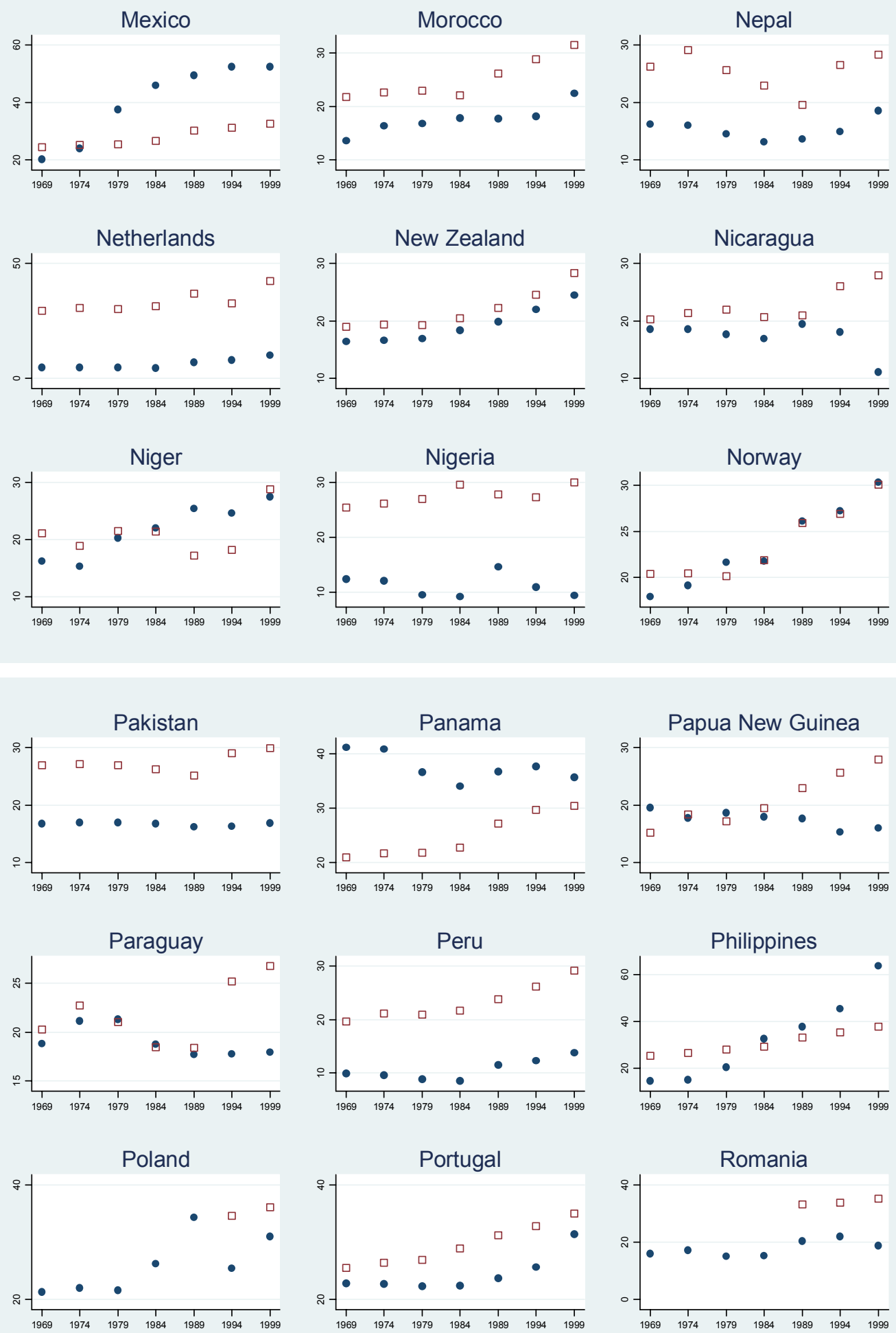

Legend: $\bullet$ : Actual EFNX; $\square$ : Predicted EFNX 
Rwanda
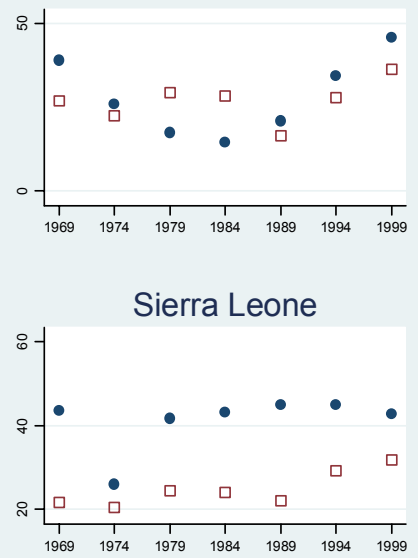

Spain

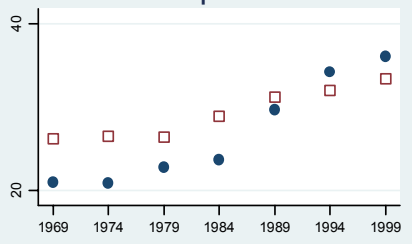

Sweden

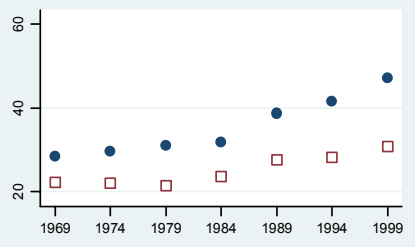

Thailand

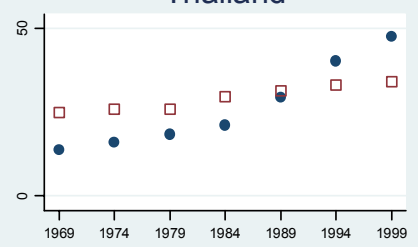

Tunisia

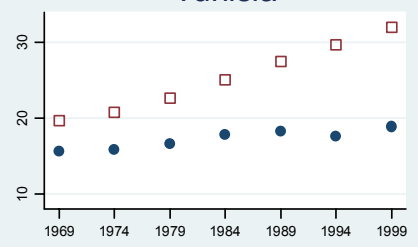

Saudi Arabia
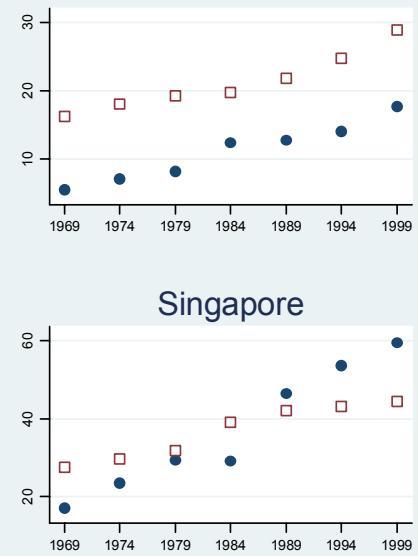

Sri Lanka

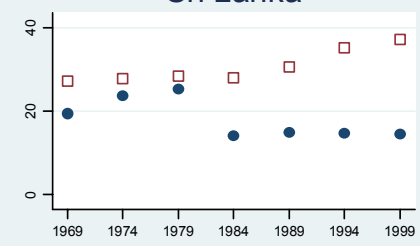

Switzerland

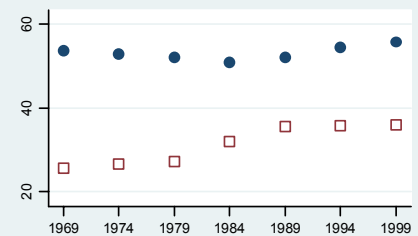

Togo

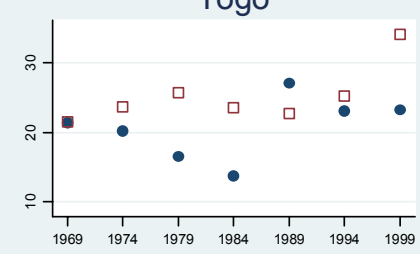

Turkey

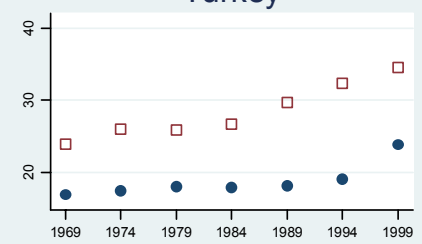

Senegal
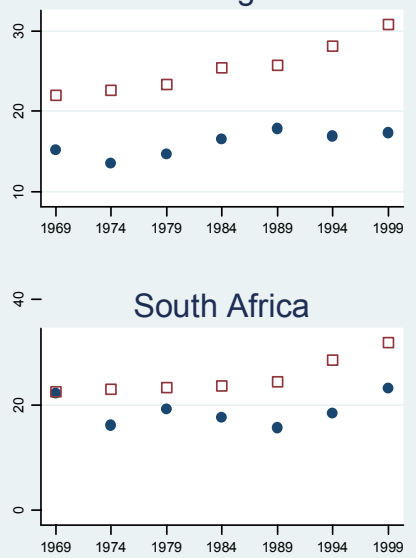

Sudan

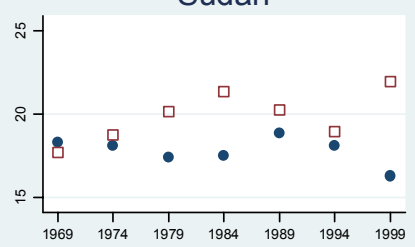

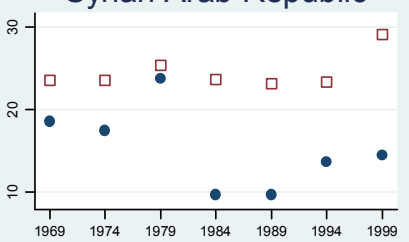

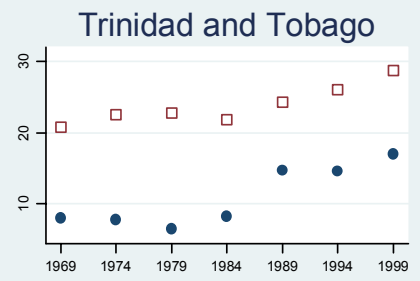

Uganda

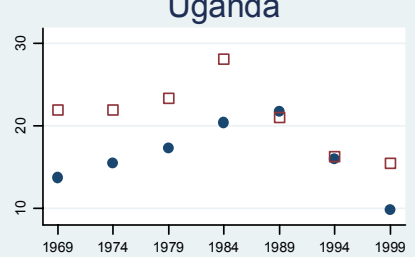

Legend: •: Actual EFNX; $\square$ : Predicted EFNX 

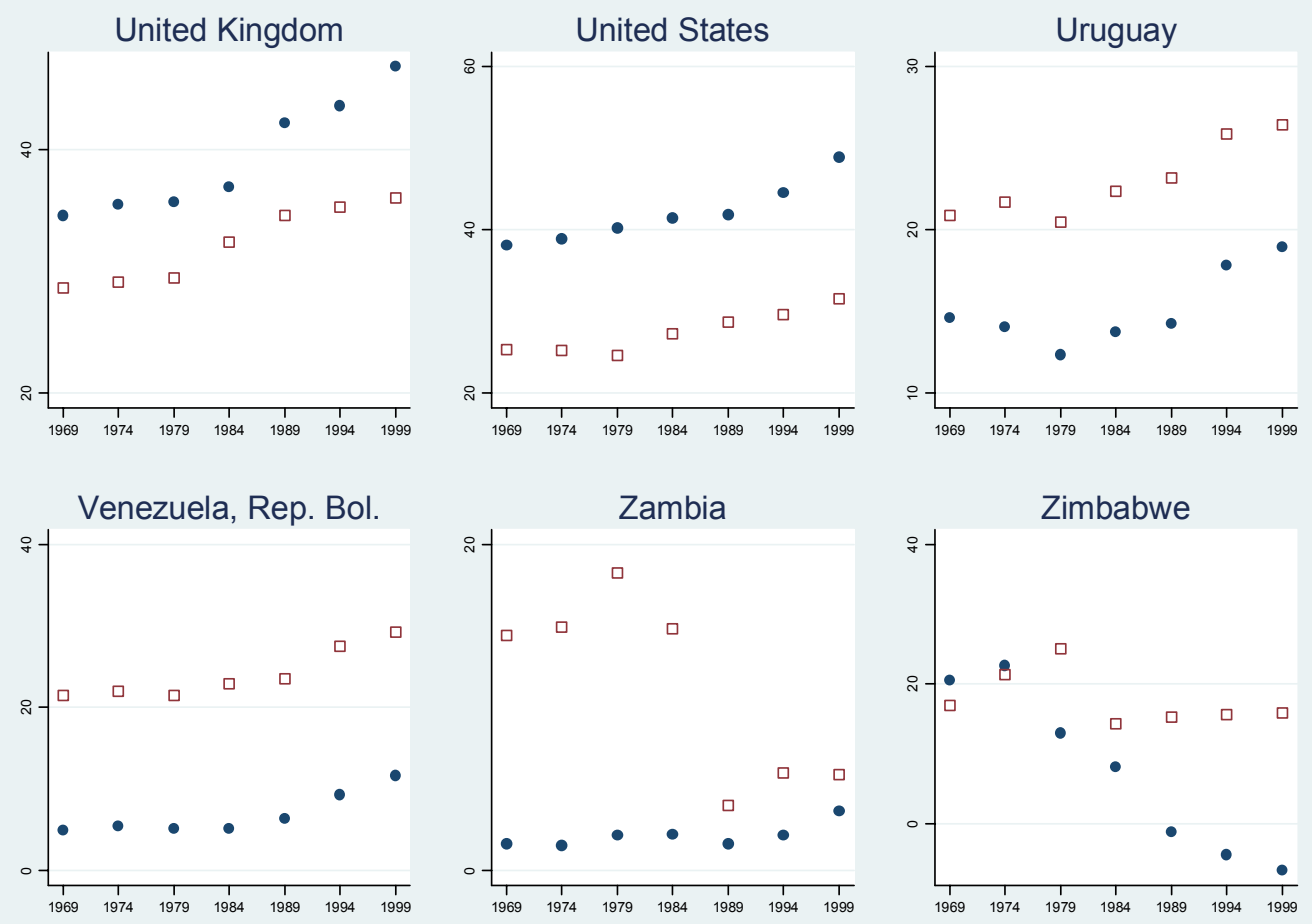

Legend: $\bullet$ : Actual EFNX; $\square$ : Predicted EFNX 


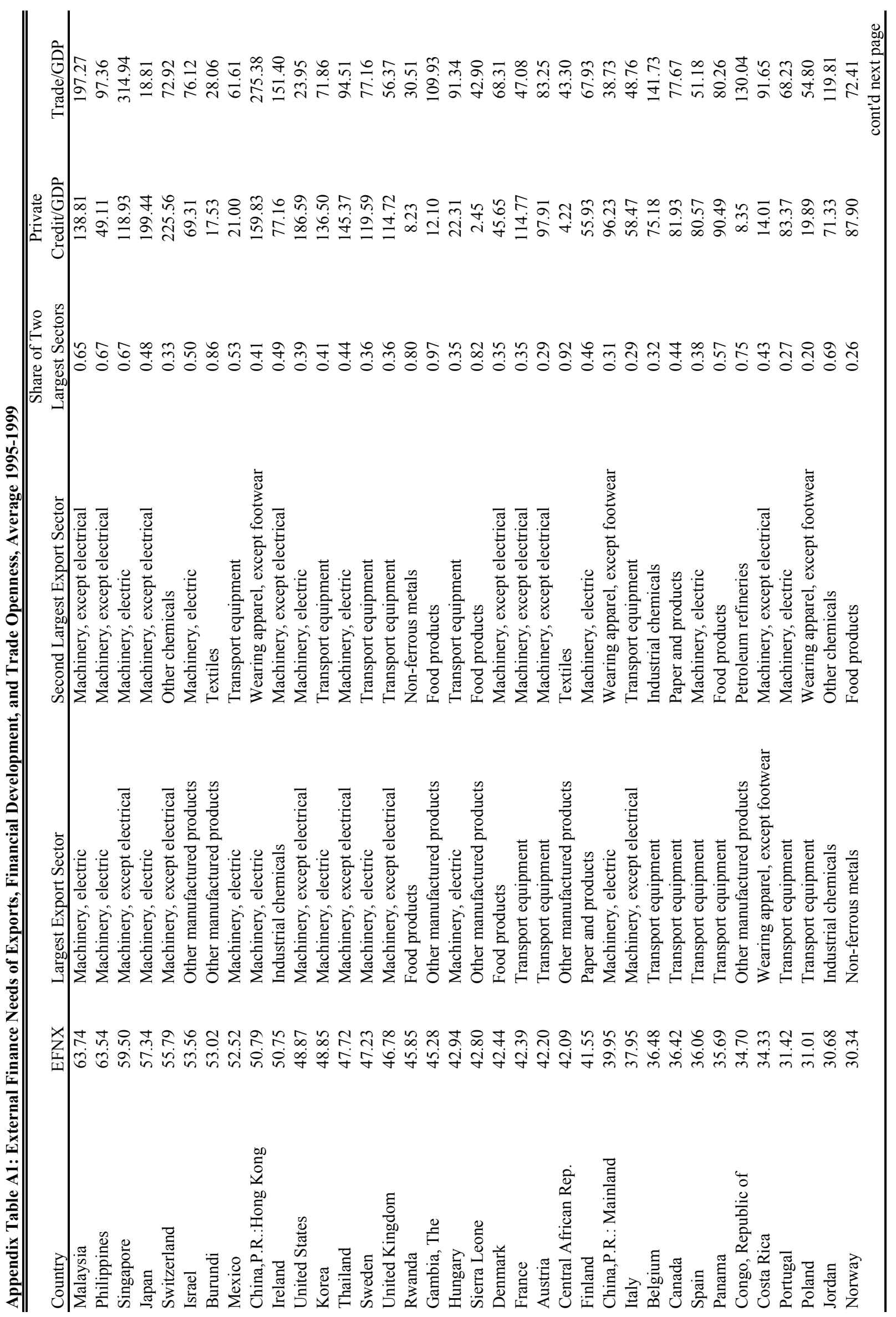




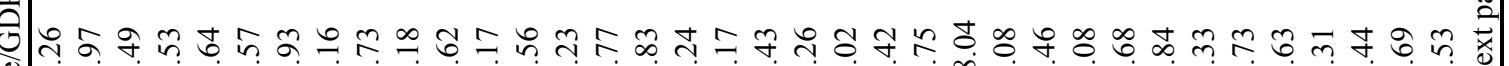

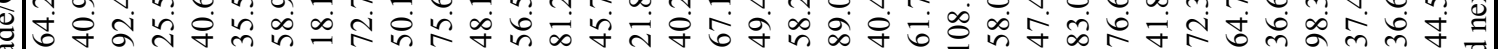

ث 传

舟

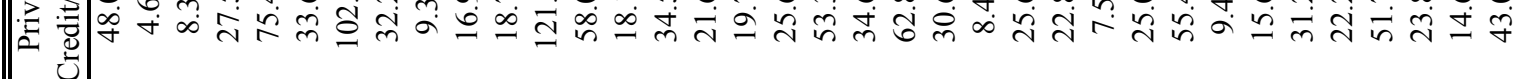

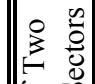

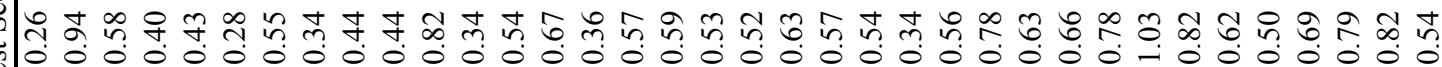

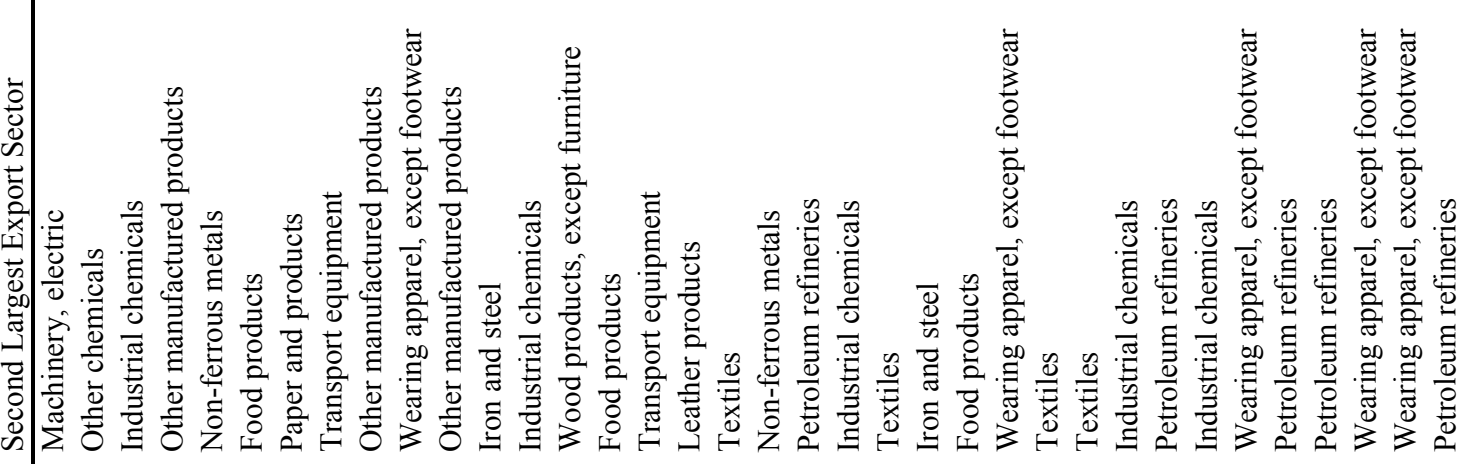

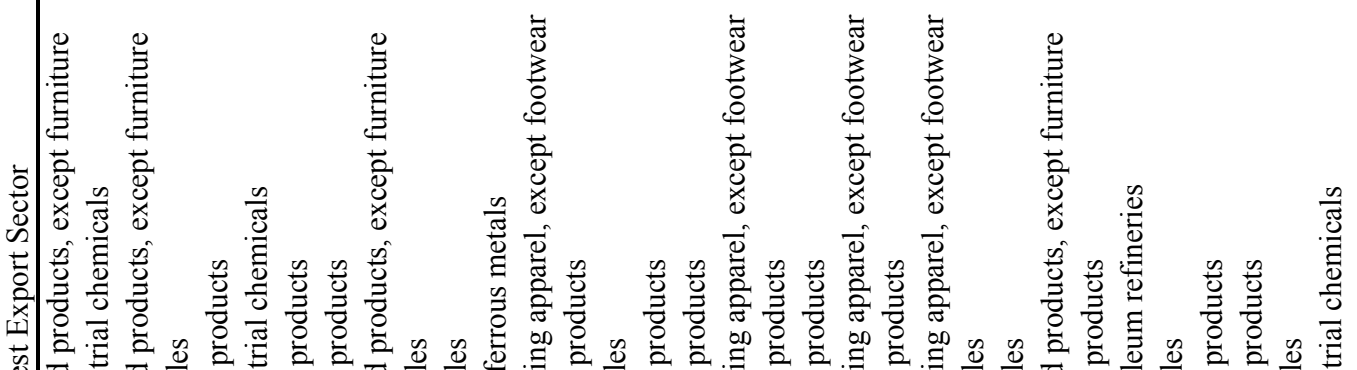

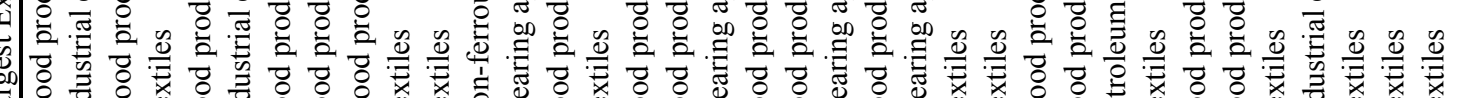

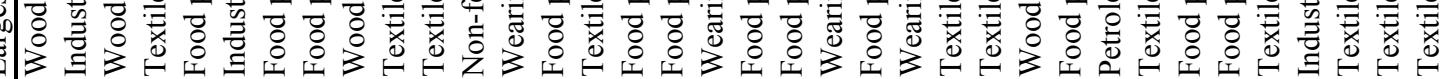

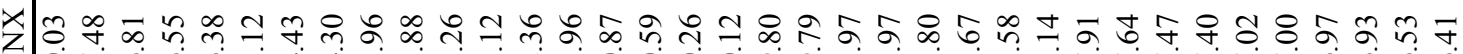

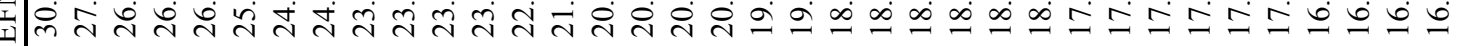

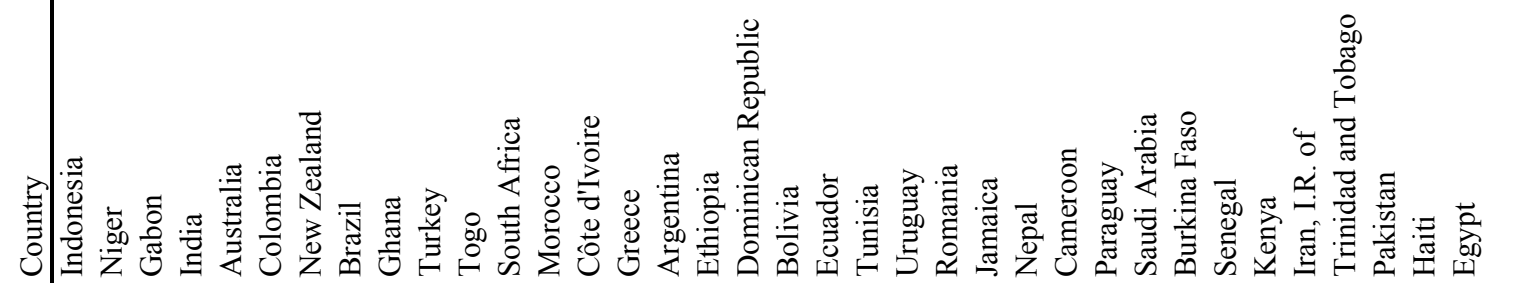






